\title{
NOTICIAS SOBRE AUSTRACISTAS ARAGONESES Y EL SECUESTRO DE SUS BIENES*
}

\author{
SERGIO SÁNCHEZ GARCía
}

\section{INTRODUCCIÓN}

Este artículo recoge básicamente la información de dos fuentes inéditas localizadas en el Archivo General de Simancas ${ }^{1}$ y en el Archivo Histórico de Protocolos Notariales de Zaragoza ${ }^{2}$, complementada con datos no publicados de mi tesis doctoral ${ }^{3}$ y diversas noticias bibliográficas. Con todo ello se pretende aportar nuevos datos acerca de elementos austracistas aragoneses, algunos conocidos, pero la mayoría no. De varios, los que fueron ciudadanos de Zaragoza hasta la extinción del concejo en 1707, se ofrecen aproximaciones biográficas con datos sobre su labor política en el gobierno municipal o en otras instituciones. También se aportan todas las noticias localizadas sobre los bienes secuestrados de muchos de ellos y su gestión. Finalmente, de un grupo importante sólo se proporciona su nombre, pero esto puede servir de indicio o pista

\footnotetext{
* Este trabajo ha sido financiado por el Ministerio de Educación y Ciencia, Plan Nacional 2003-2006, proyecto: Migraciones, redes sociales y mercado (siglos XVI-XVIII) (BHA, 2003, 00778).

1. Archivo General de Simancas. Secretaría y Superintendencia de Hacienda, legajo 972. La información procede de las páginas dedicadas a Aragón de un libro encuadernado, paginado e inserto en el legajo, con información de la Contaduría General de Bienes Confiscados. Se ofrece información de bienes confiscados y sus titulares en Castilla, Aragón (dividido en rentas comunes y eclesiásticas), Valencia, Cataluña (dividido en rentas comunes y eclesiásticas), Mallorca e Indias.

2. Archivo Histórico de Protocolos Notariales de Zaragoza. Notario real Roque Antonio Núñez. La información se encuentra en dos protocolos, el primero de ellos, al que le corresponde la signatura caja 5557, contiene datos desde el 10 de octubre de 1707 hasta el 14 de agosto de 1710; el segundo, con la signatura caja 5558, contiene datos desde mayo de 1711 hasta fines de 1716. Ambos están hechos en papel sellado. En los anexos 1,2 y 3 mencionaré simplemente el número de las dos cajas.

3. Sergio SÁnChez GARCía. Del concejo al ayuntamiento. Cambios y permanencias en el gobierno municipal de Zaragoza (1650-1750), tesis doctoral en proceso de publicación, defendida el 13 de enero de 2005 en la Universidad de Zaragoza.
} 
para estudios locales sobre este período o temática, los cuales podrán en el futuro completarlo convenientemente.

La guerra de Sucesión en Aragón no es un tema bien conocido, a pesar de algunos esfuerzos realizados en esta línea ${ }^{4}$. Las destrucciones de archivos fundamentales con motivo del Segundo Sitio de Zaragoza en 1809, junto con otros percances menores, han dificultado cualquier labor investigadora sobre la historia medieval y moderna aragonesa. Se necesita gran esfuerzo e incluso suerte para intentar reconstruir los hechos con fuentes complementarias de otros archivos institucionales ajenos a los del antiguo reino de Aragón. Los datos que aquí aparecen se han conseguido con este método, ya que el hallazgo de estas fuentes fue casual y en el curso de la investigación para la realización de la tesis de doctorado. Su interés reside en que ofrece información muy concreta sobre personas y bienes vinculados al bando perdedor del conflicto sucesorio. Por tal motivo, y atendiendo la línea temática que se ha propuesto para el número de esta revista, he querido darla a conocer, elaborándola y complementándola en la medida de lo posible.

La fuente localizada en el archivo notarial de Zaragoza recoge los actos testificados por el notario Roque Antonio Núñez (sólo ejerció desde 1707 hasta 1716, o sólo se han conservado los de estos años), muchos de los cuales, aunque no todos, están relacionados con la administración de bienes secuestrados a austracistas dentro del territorio aragonés (ápocas o cartas de pago otorgados por percepción de dinero, adjudicación de la gestión de bienes y presentación de fianzas para lo mismo, etc.). También se alude a fianzas otorgadas por personas sospechosas a las que se liberó de la cárcel, pero podían ser llamados a juicio o convocados. En un principio pensé en la posibilidad de que este notario fuera el secretario de la Junta de Secuestros creada por

4. Además de las noticias que aparecen en la obra pionera de KAMEN, Henry. La guerra de Sucesión en España. 1700-1715, Barcelona, Grijalbo, 1974, hay que mencionar el libro de Borrás GuALIS, Gonzalo María. La guerra de Sucesión en Zaragoza, Zaragoza, Institución «Fernando el Católico», 1972, los trabajos inéditos de Pérez Álvarez, María Berta. La ciudad de Zaragoza durante la Guerra de Sucesión: 1702-1715, memoria de licenciatura leída en la Universidad de Zaragoza en junio de 1990; y La guerra de Sucesión en Aragón, tesis de doctorado leída en la Universidad de Zaragoza; los trabajos de ARMILLAS VICENTE, José Antonio. «La utilización de la sátira política como fuente: Aragón durante la guerra de Sucesión», en Metodología de la investigación cientifica sobre fientes aragonesas. VII, Zaragoza. I.C.E., 1992, pp. 459-467, y ARMILlas VICENTE, José Antonio y Molinos, Maria Isabel. «Sátira política en Zaragoza durante la Guerra de Sucesión (1707)», en Estudios en homenaje al Dr: Antonio Beltrán Martínez, Zaragoza, Universidad de Zaragoza, 1986. En los últimos años destacan los trabajos de Solís, José, empezando por su tesis doctoral inédita, La administración española del archiduque Carlos de Austria, y varios artículos: «Las Juntas de Secuestros y Confiscaciones del Archiduque Carlos en Cataluña, Aragón y Valencia», en Anuario de Historia del Derecho Español, tomo LXIX, Madrid, 1999, pp. 427-459; o «La magistratura austracista en la Corona de Aragón», en Manuscrits, n. ${ }^{\circ} 23$, Barcelona, 2005, pp. 131-150. También mencionar del que escribe estas líneas un trabajo reciente que analiza algunas consecuencias del conflicto: SÁNCHEZ GARCíA, Sergio. «La llegada de los Borbones. Transformación y adaptación en la elite de gobierno de la ciudad de Zaragoza), en José Antonio SALAS (Coord.). Migraciones y movilidad social en el Valle del Ebro en la Edad Moderna, Bilbao, Prensas Universitarias de la Universidad del Pais Vasco. En prensa. 
orden de Felipe $V$ en 1707 y posteriormente en 1711, pero no he localizado información que lo corrobore, aunque no es descartable. Un hecho que podría apoyar esta idea es su dedicación, ya que fue regente de la escribanía principal del zalmedina o juez real de Zaragoza en la última década del siglo XVII, y en octubre de 1702 fue nombrado escribano del Juez de Encuestas de Aragón. Su padre, del mismo nombre, también fue escribano del zalmedina y ciudadano, es decir miembro de la oligarquía zaragozana que ejercía el gobierno municipal, de ahí que nuestro hombre también hiciera gestiones en 1680 para acceder a bolsa $5 .^{a}$ de los ofícios de la ciudad y en 1705 a $4 .^{a}$ bolsa ${ }^{5}$.

La segunda de las fuentes mencionadas, guardada en el Archivo General de Simancas, es una relación de Miguel Rossa, Contador General de Bienes Confiscados, dada el 17 de septiembre de 1722, acerca de los valores brutos y netos, descontadas las cargas de justicia y otros gastos, que habrían producido los bienes y rentas secuestrados en Aragón en 1721 y teniendo en cuenta lo que habían generado en 1720. Esta relación fue elaborada con los datos remitidos por la Superintendencia General de Rentas y Confiscaciones de Aragón. Se presenta en forma de un listado de personas ordenado por orden alfabético del nombre y los demás datos sobre sus bienes ${ }^{6}$.

Para aprovechar plenamente toda la información que contienen estos documentos me ha parecido conveniente organizar el artículo comenzando con unas breves consideraciones sobre la gestión de los bienes de austracistas. A continuación reúno algunas noticias sobre la identidad de los mismos, prescindiendo de los nobles, que son pocos, mejor conocidos y con una trascendencia que en ocasiones desborda las fronteras aragonesas. Finalmente presento los siguientes anexos: un listado de las personas recompensadas con bienes de austracistas en Aragón; un listado de personas sospechosas que fueron liberadas bajo fianza; un listado de personas con datos sobre bienes secuestrados, encabezados por la nobleza, que muestra toda la información recogida sobre la gestión de los mismos (quiénes los tenían a su cargo, qué bienes eran, a quién se arrendaron, qué fianzas se otorgaron, etc.), dejando sin detallar únicamente los poseedores y cuantías de pensiones de censales o violarios de los nobles (ya que la relevancia de estos bienes en el conjunto de los que poseyeran es difícil de precisar); un listado de todas las personas que aparecen en la certificación de 1722, muchos de los cuales se mencionan en los protocolos notariales de Roque Antonio Núñez, lo cual refuerza el

5. Archivo de la Corona de Aragón, legajos 107, 109, 110 y 111. Archivo Municipal de Zaragoza, libro de actos comunes de 1680 , f. 291 , y caja 7771, n. ${ }^{\circ} 1$. Archivo Histórico Nacional, sección Consejos, libro 2273 , f. $198 \mathrm{v}$ y libro 2287 , ff. $73 \mathrm{r}-75 \mathrm{r}$.

6. Sobre esta última fuente hay que explicar algunas peculiaridades. Recoge 212 entradas, 6 sobre titulados. Del resto hay 193 con un titular, 3 que abarcan cada una a dos personas, (en dos casos parecen familiares y en el otro no), y también aparecen 10 entradas con nombres y apellidos repetidos. La explicación más razonable sería que estas entradas correspondían a bloques de bienes y en 3 casos tienen dos propietarios y en 10 , siendo el mismo propietario, se puede pensar que estaban situados en diferentes lugares o se consideraron separadamente por alguna razón.

Sólo he detectado un error, ya que en la entrada de don José Pérez de las Aguas, la renta de sus bienes supuso 320 reales de plata, los gastos también 320 reales y sin embargo el saldo es 320 , cuando debería ser 0 . 
interés de ambas (el orden alfabético se ha cambiado, prefiriendo el de los apellidos; además se incluyen en primer lugar los nobles, y después todos los demás).

Un caso aparte es el último anexo, ya que consiste en una aproximación biográfica profesional a todos aquellos mencionados en las dos fuentes antedichas que fueron ciudadanos de Zaragoza, es decir miembros del grupo dirigente del gobierno municipal que fue radicalmente alterado con los decretos de Nueva Planta. Con la aparición del ayuntamiento algunos miembros de antiguas familias de ciudadanos fueron nombrados regidores, pero es notorio el alejamiento de apellidos que habían sido permanentes durante décadas y generaciones en las actas municipales del concejo. Se intuía y se tenían algunos datos que explicaban este fenómeno como una consecuencia del hecho de que muchos fueron austracistas, pero nos faltaban datos concretos de muchos. Estas fuentes nos proporcionan dicha confirmación para un buen número de ellos, de ahí que me parezca importante incorporar los datos que precisan quiénes fueron y qué habían hecho hasta la guerra de Sucesión.

El material no permite un estudio suficientemente profundo sobre esta materia, tal y como se ha hecho en otros lugares ${ }^{7}$, pero sin embargo es un importante paso adelante sobre lo que existía hasta ahora para Aragón, y proporciona información que abre posibilidades de estudio.

\section{LA GESTIÓN DE LOS BIENES SECUESTRADOS DE AUSTRACISTAS ARAGONESES}

No aparecen datos sobre los miembros relevantes de la Junta de Secuestros, sí sobre el tesorero de la misma y algunos oficios subalternos. Don Domingo Gascón figura en numerosos actos como tesorero desde 1707 hasta $1710^{8}$. Don Juan Francisco Lasala, vecino de Zaragoza, fue contralor de los efectos confiscados a disidentes y en 1709 recibió 2.833 reales y medio de plata de dichos efectos por su salario y gages de tres meses, que incluyeron presentación de cuentas?. Don Antonio Pérez de la Hera recibió de la Junta 12 libras en 1710 por diligencias hechas en la secretaría de dicha Junta $^{10}$. Un caso algo especial es el de don Melchor de Flores, arquero y depositario general de rentas reales, que recibió de la Junta 2.000 reales de plata en 1710 por gastos

7. Para los territorios valencianos destaca Jesús PRADELls NADAL. Del foralismo al centralismo. Alicante (1700-1725), Alicante, 1984; M." Carmen PÉrEZ APARICIO. «La política de represalias y confiscaciones del Archiduque Carlos en el País Valenciano. 1705-1707», en Estudis. Revista de Historia Moderna, n. ${ }^{\circ}$ 17, Valencia, 1991, pp. 149-196. Para Cataluña Pedro VOLTES BOU. Barcelona durante el gobierno del Archiduque Carlos de Austria (1705-1714), 2 vols., Barcelona, 1963, t. I, pp. 221-222, y t. II, p. 71.

8. AHPNZ, caja 5557, protocolo de los años 1707-1710 del notario Roque Antonio Núñez, f. 521. En un acto de 18-3-1710 se escribe que era hidalgo y gobernador del estado del marqués de Camarasa, conde de Ricla y demás bienes de su casa.

9. Idem, f. 419. El 27 de septjembre de 1709 Lasala presentó como fianza de acreedor con mejor derecho a Juan Beltrán de Fonsdeviela, vecino de Zaragoza.

10. Idem, f. 497. El acto se realizó el 16 de febrero de 1710 . 
de reparación en la contaduria de rentas reales" ${ }^{11}$. Pedro Ramón de la Cueva, portero de la real chancillería ${ }^{12}$ y de la Junta recibió en julio de 1710 dos doblones de a dos escudos de oro por su ocupación de portero de la Junta ${ }^{13}$.

De la consulta de los actos que aparecen en los protocolos del notario Roque Antonio Núñez se deducen numerosas noticias acerca de cómo se organizaba la gestión de los secuestros. La gestión de las grandes casas nobiliarias, con importantes patrimonios, era transferida en bloque. Sin embargo otros administradores tenían a su cargo un tipo de bienes de diferentes propietarios. Así, Juan Francisco Sobrecasas, vecino de Zaragoza, fue nombrado arrendador de todas las casas secuestradas en Zaragoza y sus barrios el 17 de enero de 1708, así como encargado del cobro de los réditos de censos $y$ treudos de las mismas ${ }^{14}$. Y Francisco Estadilla fue nombrado el 16 de enero de 1708 arrendador de las viñas, campos y olivares en Zaragoza y sus barrios de los disidentes y ausentes ${ }^{15}$. Fuera de la capital la gestión de bienes de un ausente en cada localidad era encargada generalmente a algún habitante de la misma.

Para asegurar la correcta gestión se tomaron diferentes precauciones. En primer lugar los encargados de administrar debían otorgar fianzas ante la Junta de Secuestros que respondieran de la gestión de dicho trabajo. En segundo lugar, cuando estos administradores arrendaban bienes exigían, a los que se hacían cargo, fianzas por el pago de las cantidades señaladas. A la hora de autorizar pagos de los que tuvieran que responder los bienes de secuestrados, además de revisar los documentos que los justificaran por parte de los acreedores, la Junta de Secuestros o sus administradores exigían «fianzas de acreedores de mejor derecho», es decir, que alguien respondiera de la devolución de las cantidades si se demostraba que otro deudor tenía mejores derechos al cobro. Además se elaboraba la lógica carta de pago o ápoca que servía como recibí. La mayoría de las mismas se expidieron por la percepción de pensiones de censales, ya estuvieran cargados sobre casas nobles o sobre bienes de otros particulares.

Algunas gestiones se derivaron de la solicitud de respeto de los bienes de terceros perjudicados por secuestros, es el caso de Pedro de Ágreda, que lo demandó al haberse secuestrado los bienes de su hermana Gertrudis de Ágreda y su marido Miguel Teresa, vecinos de Alpartir. Días después, la Junta nombró al dicho Pedro administrador de todos los bienes hasta que se hicieran las particiones convenientes ${ }^{16}$. Un caso similar

11. ldem, f. 504. El acto se realizó el 22 de febrero de 1710.

12. En junio de 1698 se le concedió la portería vacante de la audiencia real por muerte de Pedro Pérez Guiral. Datos en Guembe Ruiz, Ana María. El reino de Aragón según los registros de la llamada «Real Cámara» durante Carlos II de Austria, Zaragoza, Institución «Fernando el Católico», 1984, pp. 20-28. Después de 1707 debió de ser recolocado en la chancillería.

13. Ibidem, f. 595. El acto se realizó el 13 de julio de 1710.

14. Idem, f. 41. Presentó como fianza a José Montengón, vecino de Zaragoza. Más adelante, en otro acto cuyo tema no interesa, se dice de Sobrecasas que tradujo del francés un poder porque era natural de Francia, ff. 126r-134v.

15. Idem, ff. 45r-46v. El 25 de enero de 1708 presentó como fianza a Andrés Caballo, vecino de Zaragoza. 16. Ver detalles en anexo 3. 
parece el de doña Catalina Díez y Ganaberro, vecina de Zaragoza, que dio poderes a los procuradores de la chancillería Juan Gerónimo Andosilla, José Antonio Ondeano y Francisco Ondeano para que ante la Junta defendieran los bienes y derechos que le pertenecían, seguramente por dote matrimonial, y estaban secuestrados ${ }^{17}$.

También aparecen entre los protocolos documentos derivados de dos reclamaciones alegando fidelidad, como es el caso de Gerónimo Cester, vecino de Híjar, cuya fídelidad certificó don Jaime Ric, a pesar de lo cual no le entregaban los bienes que los comisarios y jueces de su villa le habían embargado ${ }^{18}$. Y don Vicente Martínez de Luna, infanzón de Uncastillo, que pidió el levantamiento del secuestro de sus bienes ya que durante la rebelión estaba fuera de su casa, pero en lugares vecinos y no había salido del reino ${ }^{19}$.

\section{QUIÉNES ERAN LOS AUSTRACISTAS}

De la lectura de los apuntes de los protocolos de Roque Antonio Núñez se obtienen datos sobre un total de dos o tres sospechosos de austracismo, catorce casas nobiliarias con bienes secuestrados por su alineamiento evidente con el Archiduque y otros setenta individuos o familias a los que se les embargaron bienes en Aragón por lo mismo.

Al revisar la relación de 1722 se repiten los nombres de tres casas nobles y al menos cuarenta y tres de los que aparecieron en los papeles del notario, pero además se citan tres casas nobiliarias diferentes y ciento cincuenta y seis nuevos represaliados con embargos. Admitiendo algún error debido a confusiones con los apellidos, lo cierto es que disponemos de un número apreciable de individuos y familias ignorados hasta ahora.

Sobre su lugar de origen o vecindad aparecen datos exclusivamente en los protocolos de Núñez. Los tres sospechosos de austracismo que necesitaron de fianzas para salir de la cárcel eran vecinos de Zaragoza. Entre aquellos setenta cuyos bienes fueron secuestrados, y sin contar los nobles, encontramos estos datos: un vecino de Alpartir, un vecino de Sos, uno de Calatayud, cuatro de Fraga, uno de Huesca, dos de Alagón, uno de Ateca, dos de La Almunia (parientes), uno de Calatorao, uno de Tauste, uno de Odón, uno de Uncastillo, uno de Daroca, uno de Tamarite, uno de Muel, cuarenta y cuatro de Zaragoza, y por último hay seis dudosos (si bien por ciertos datos de los fiadores o la vecindad de los administradores de sus bienes uno podría ser de Zaragoza, uno de Azuara, uno de Pradilla y dos de La Almunia, quedando uno del que no se puede leer el nombre de la localidad indicativa).

17. lbidem, ff. 11 r-12r. Concedió el poder el 6 de noviembre de 1707. No se dan más datos sobre los bienes.

18. Idem, f. 21 . El 14 de noviembre de 1707 dio poder a Juan Antonio Urrea para presentarse ante la Junta de Secuestros y defender sus derechos.

19. Idem, f. 73 . El 3 de marzo de 1708 nombró a Juan Gerónimo Andosilla para que acudiese ante la Junta de Secuestros con las alegaciones. 
Una de las informaciones más sugerentes es la relativa al austracismo presente entre los titulares o miembros en algún escalafón de las instituciones civiles del Rey, del Reino y de la capital de éste, Zaragoza.

Miembros de la lugartenencia o administración virreinal fueron José de Villarreal, escribano de mandamiento de la misma y archivero desde octubre de $1679^{20}$. Otro escribano del mismo origen, nombrado en 1696, era Joaquín López de Cenedo ${ }^{21}$. Su significación austracista es inexcusable, ya que fue secretario de la Junta de Secuestros organizada por el Archiduque en 1706 y oficial 2. de la Protonotaría del Consejo de Aragón del Archiduque desde enero de $1707^{22}$.

Miembros de la Audiencia real fueron Agustín Estanga, que antes de ocupar este cargo había sido lugarteniente del Justicia desde marzo de 1662, miembro de la sala criminal de la audiencia desde octubre de 1684, de la civil desde julio de 1687, abogado fiscal del rey desde julio de 1699 y asesor del gobernador del reino desde 1702 hasta fines de $1705^{23}$.

Pedro Cavero fue miembro de la sala civil desde julio de 1651 hasta su jubilación en 1676, y antes perteneció a la criminal ${ }^{24}$. Es éste un caso dudoso, por cuestión de fechas, pudiendo ser un hijo del magistrado el que aparece en la certificación de 1722.

Don Manuel Ventura de Contamina fue miembro de la sala civil desde agosto de 1690, y antes perteneció a la criminal desde 1677, hasta donde ascendió desde una lugartenencia del Justicia, obtenida en marzo de $1661^{25}$.

José Ozcáriz y Ferrer fue miembro de la sala criminal por concesión de la primera vacante que surgiese en diciembre de 1690. Posteriormente perteneció a la audiencia de Aragón nombrada por el Archiduque, asesor del Gobernador de Aragón y miembro de la Junta de Secuestros ${ }^{26}$.

Gerónimo Félix del Río se convirtió en procurador fiscal del rey en julio de $1680^{27}$.

Francisco Ibáñez de Aoíz era escribano de mandamiento de la audiencia real por concesión a su mujer, y dispuso de este oficio en marzo de 1678 , después de gozarlo tres años. Era además notario causídico ${ }^{28}$.

\footnotetext{
20. Sobre el cargo ver Guembe Rulz, Ana María. El reino de Aragón..., pp. 16-17, 161-163

21. Idem, pp. 16 l-163.

22. Solis, José. «Las Juntas de secuestros y confiscaciones..., pp. 448 y 454.

23. AHN Consejos, libro 2287, ff. 51v-55r y 154r-156v. ACA, Registros, n. 20, f. 13v. GuemBE RuIz, A. M. El reino..., pp. 37-39,60-61.

24. ACA, Registros, n. ${ }^{\circ}$ 15, ff. 42v-45v. Guembe Ruiz, A. M. El reino ..., pp. 37-39.

25. ACA, Registros, n. ${ }^{\circ}$ 18, f. 69. Guembe RuIz, A. M. El reino..., pp. 37-39, 172.

26. Solís, José. «Las Juntas..., pp. 448 y 454.

27. GUEMBE RuY, A. M. El reino..., p. 61.

28. Idem, pp. 55-56.
} 
Relacionado con la Bailía General de Aragón aparece Esteban Esmir Serán y Casanate, que consiguió en marzo de 1678 la futura sucesión de la plaza de receptor de la misma, que ocupaba su padre Juan Antonio Esmir ${ }^{29}$.

Finalmente Gerónimo Nicolás Torrijos obtuvo en octubre de 1698 el permiso para disponer de una vacante de escribanía de la corte del Justicia, que gozaba su suegra Manuela Gil, u otra plaza que quedara vacante ${ }^{30}$.

Otro grupo de interés son los ciudadanos de Zaragoza, ya que aparecen los nombres de treinta de ellos entre las dos fuentes que trabajamos. Algunos se han mencionado ya al hablar de las personas vinculadas a instituciones reales o regnícolas. De todos se presenta una pequeña biografía con datos sobre su vida pública municipal en el último anexo. Sí es importante señalar que bastantes pertenecían a familias de gran prestancia en el gobierno de la ciudad, como fueron Pedro José Andrés, Gerónimo Antón y Sayas, Manuel Ventura de Contamina, Esteban Esmir Serán, Agustín Estanga, Francisco Ibáñez de Aoíz, José Ozcáriz y Ferrer, José Miguel Pérez de las Aguas, José Suelves $^{31}$, Andrés Torrijos y Gerónimo Torrijos. Especialmente señalados quedaron los ciudadanos que asumieron el gobierno de la ciudad desde agosto hasta diciembre de 1710, tras la batalla de Zaragoza, siendo numerosos los citados. Otros tuvieron un perfil personal y familiar mucho menos relevante antes o durante la guerra.

Sería arriesgado extraer conclusiones definitivas con estos datos. A primera vista destaca la importancia de los austracistas afincados en Zaragoza y miembros de su gobierno municipal, pero esto podría deberse al origen de una de las fuentes, el archivo notarial de la ciudad, $\mathrm{y}$ al hecho de que todas las instituciones del reino y del rey tenían también aquí su sede y era lógica la vecindad y posesión de bienes en la misma. La relación de 1722, que corresponde a bienes en todo Aragón, reúne muchos más apellidos y la proporción de los zaragozanos, al menos de los que sabemos que lo eran, es menor.

Sí que se puede destacar la relevancia de muchos de los apellidos de ciudadanos austracistas, aunque es bien cierto que algunos borbónicos, tales como los Pérez de Nueros o los Torrero, también pertenecían a largas y prestigiosas sagas ciudadanas ${ }^{32}$. Esto redundaría en esa visión que viene presentando la historiografía de este conflicto al hablar sobre Aragón: un territorio dividido en su lealtad, menos radicalizado, frente al predominio austracista en Cataluña o el borbónico en Castilla.

En cuanto a la cuantía de las rentas de bienes embargados destacan sin duda las de las casas nobles, salvo la condesa de Centellas. En el resto hay un predominio de

29. Idem, p. 19

30. Idem, pp. 147-148.

31. Su importancia fue considerable, ya que fue nombrado ministro de la real audiencia creada por el Archiduque en 1706, comisario de la Junta de Secuestros, regente del consejo de Aragón y asesor del consejo de Cruzada. Datos tomados de Solís, José. «Las Juntas...», pp. 448 y 459.

32. En los apéndices de mi tesis doctoral, SÁnCHEz García, Sergio. Del concejo... pueden verse los ciudadanos de los últimos 60 años anteriores a 1707, datos sobre los austracistas y también datos sobre los que pervivieron en el ayuntamiento como regidores. Los hay significativos en ambos lados. 
rentas menores de 1.000 reales de plata al año. El total suponía para la real hacienda, a principios de los años veinte del siglo XVIII, después de restar cargas de justicia y gastos, algo más de 100.000 reales de plata. Habría que saber qué cantidades por estas mismas fechas seguían consignadas para compensar a los que habían sido leales y cuál sería el saldo hacendístico. Pero esto es materia que necesitaría de más fuentes, aunque son aprovechables los datos del primer anexo, y corresponde al reverso de esta historia, bien distinto: la de los vencedores de la contienda.

ANEXO 1

\section{PERSONAS QUE RECIBIERON CANTIDADES PROCEDENTES DE BIENES SECUESTRADOS}

El 4-12-1707 don Antonio de Torres, veguer de Montblanc, vecino de Tárrega y residente en Zaragoza, apoderó a José y Juan Castillo para que pudieran recibir de la Junta de Secuestros 10 doblones mensuales que S. M. le había concedido sobre estos bienes. La segunda paga correspondía al 5 del presente mes, y así en los venideros (caja 5557 , f. 28).

E1 25-6-1708 don Juan Rodríguez Peña, residente en Zaragoza y teniente de caballos del regimiento del Rosellón nuevo, del que era coronel don Juan Cereceda, apoderó a José Ubago, escribano receptor de la chancillería, para que cobrase 2.000 ducados asignados por S. M. en real cédula. Ya había recibido 25 doblones de a dos escudos de oro (caja 5557, f. 116).

El 25-2-1709 don Juan Gerónimo de Blancas, corregidor de Zaragoza, tras presentar real cédula de 15 de enero de 1709 por la que se le adjudicaba la hacienda de Antonio Matías de la Fuente, vecino de Alagón, nombró procurador para recibirla en Daroca y Murero a don Martín de Michelena (caja 5557, f. 369).

E1 25-2-1709 don Juan Gerónimo de Blancas, corregidor de Zaragoza, tras presentar real cédula de 15 de enero de 1709 por la que se le adjudicaban los bienes de los Orera, nombró como procurador para recibirlos en Daroca y Murero a don Martín de Michelena (caja 5557, f. 369).

E1 8-8-1709 la Junta entregó, por mano de un escribano de la chancillería como procurador, a don Francisco Portell, del consejo de Castilla y de Cruzada, que vivía en Madrid y a quien el rey había consignado de los secuestros de Aragón 188 doblones de a 2 escudos de oro y 31 reales 17 dineros de plata, dicha cantidad pero de la siguiente forma: 50 doblones al contado y 138 doblones 31 reales 17 dineros con dos letras dadas por don Martín Ezpeleta, vecino de Zaragoza, en nombre de la contaduría de asentistas del ejército, a favor de la Junta por granos y cantidades adeudadas a la misma (caja 5557, f. 412).

El 11-12-1709 don Baltasar Barduzal, vecino de Zaragoza, y con poder del marqués del Alcázar, del consejo de Castilla y encargado por el rey de la administración de los bienes secuestrados de José Luzán, presentó como fianzas a don Antonio de Leiza y Eraso y don José Soriano y Gan, vecinos de Huesca. Además el rey había adjudicado 
sobre dichos bienes 1.000 escudos de una vez para don José Antonio Torrejón (caja 5557, ff. 437r-440v).

E1 16-12-1709 la Junta pagó a don Juan de Escursa, veguer de Tárrega, 30 doblones de a dos escudos de oro por la merced otorgada por el rey de 10 doblones al mes, a cargo de los bienes secuestrados (caja 5557, f. 444). El 19-7-1710 recibió otros 10 doblones de a dos escudos de oro (caja 5557, f. 598).

E1 13-1-1710 la Junta pagó a Pedro Arnal, vecino de Alcañiz, 22 libras 8 sueldos que se le debían por una merced del rey sobre bienes confiscados de 4 reales de plata al día. La entrega correspondía al periodo desde el 6 de noviembre al 31 de diciembre de 1709 (caja 5557, f. 476). El 8-3-1710 el mismo recibió de la Junta 236 reales de plata por enero y febrero (caja 5557, f. 513). El 27-5-1710 recibió 368 reales de plata por marzo y abril (caja 5557, f. 567).

E1 3-2-17 10 la marquesa de Gironella, María Francisca de Agulló y Zagarriga, mujer de don Francisco de Agulló Pinós y Zagarriga, coronel de caballería, otorgó carta de pago a la Junta por valor de 100 doblones de a dos escudos de oro, por dos años de la merced que el rey le tenía hecha sobre bienes secuestrados del reino (caja 5557, f. 486).

El 7-2-1710 don Pedro Marín de Resende, vecino de Zaragoza, recibió de la Junta 450 libras a cuenta de la real cédula en que se le otorgaron de los bienes confiscados (caja 5557, ff. 489r-490v).

E1 21-2-1710 don José Font, menor, con poder de José Font, mayor, recibió de la Junta 10 doblones de a dos escudos de oro por un libramiento hecho por real cédula contra secuestros (caja 5557, f. 503).

E1 22-2-1710 don Miguel Ramón Correxas, vecino de Zaragoza, recibió de la Junta 100 libras de bienes de don Francisco Esmir que se le habían adjudicado por real cédula [no explica el motivo] (caja 5557, f. 505).

El 25-2-1710 don José Español, residente en Zaragoza, recibió de la Junta 11 doblones y 9 reales de plata por concesión real. También de la Junta, pero por mano de don José Torrente, administrador del secuestrado condado de Ribagorza, recibió 7 doblones 23 reales de plata (caja 5557, f. 506).

E1 15-3-1710 Domingo López, Domingo Beltrán y Juan de Nicolao, vecinos de la villa de Gardi, en el valle del Roncal, recibieron de la Junta 20 libras [no explica motivos] (caja 5557, f. 518).

El 20-3-1710 Sebastián Mombiela y Francisco Valladolid, labradores vecinos de Zaragoza, recibieron de la Junta 56 reales de plata de bienes confiscados [no explica motivos] (caja 5557, f. 522).

El 26-3-1710 don Miguel Alcaine, vecino de Villarroya, recibió de la Junta 40 libras concedidas por real cédula (caja 5557, f. 528).

El 24-4-1710 el Hospital de Gracia de Zaragoza recibió de la Junta 48.023 reales 15 dineros de plata que le pertenecían del estado de Coscojuela, por 1709, y restados los cargos, censos y gastos de administración, entre ellos 200 reales de plata dados al notario por las cartas de pago concedidas (caja 5557, f. 541). 
E1 26-4-1710 don Lorenzo de Aguirre, vecino de Huesca y regidor de la ciudad, recibió de la Junta, a cargo del estado de Plasencia (concretamente de la baronía de Argavieso) 300 ducados de vellón, equivalentes a 220 pesos de plata asignados por real cédula, y correspondientes al periodo que finalizó el 27 de junio de 1709 (caja 5557, f. 542).

El 5-5-1710 el doctor don José Alós y Terrer, oidor de la chancillería de Valladolid, recibió de la Junta 64 libras asignadas por real cédula sobre bienes secuestrados (pertenecían dichos bienes a don José Borau, don Gerónimo Torrijos, don José Miguel Pérez de las Aguas, don Lucas Laporta, don Marcelo de Aínsa y al estado de Plasencia) (caja 5557, f. 546).

El 17-5-1710 el doctor don Jaime Borruel, vecino de Zaragoza, recibió de la Junta 1.000 reales de plata [no explica el motivo] (caja 5557, f. 557).

El 20-5-1710 don Pedro Luis Fernández de Híjar, conde de Belchite y comendador mayor de la encomienda de Montalbán, recibió de la Junta 172 libras 15 sueldos 6 dineros en forma de uvas de la cosecha de 1709 de varios secuestros [no explica el motivo] (caja 5557, f. 558).

El 30-5-1710 don Juan Rodríguez Peña, residente en Zaragoza, recibió de la Junta 400 reales de plata a cuenta de los 2000 ducados que por una vez se le asignó en una real cédula (caja 5557, f. 570).

El 23-6-1710 sor Manuela Ibáñez de Aoíz, del convento de la Encarnación de Zaragoza, recibió de la Junta 60 libras por las pensiones de un violario (caja 5557, f. 580).

El 29-6-1710 don Guillermo Belthober, coronel de dragones del regimiento de Picolques, recibió de la Junta 400 reales de plata (caja 5557, f. 586).

El 30-6-1710 don José Henarritos, escribano receptor de la chancillería, recibió de la Junta 10 reales de a ocho [no explica el motivo] (caja 5557, f. 588).

ANEXO 2

PERSONAS SOSPECHOSAS QUE FUERON LIBERADAS AL SER AFIANZADOS POR OTROS

El 23-10-1707 fue afianzado Pedro Experiqueta, vecino cirujano de Zaragoza, preso por orden del zalmedina Juan Gerónimo de Blancas, por hablar «desconpassadamente contra la real persona de Su Magd. y su gobierno anttes de la sedicion y despues», por Antonio Ximeno, maestro carpintero, que otorgo "fianza de la haz». Estaba en la cárcel real y esto ocurrió previa visita de dos oidores y del zalmedina (caja 5557, f. 3).

El 13-11-1707 fue afianzado José de Zuznaba, maestro cubero, preso por orden del zalmedina Juan Gerónimo de Blancas, por hablar mal del rey, si bien no se había podido justificar dicho acto, por Pablo Crespo, maestro de coches y carros, vecino de Zaragoza (caja 5557, f. 19).

El 24-1-1709 don Francisco de Tena, vecino de Zaragoza, se hizo fianza de Francisco Simón Juárez, que estaba en la cárcel de corte y se le daba como prisión 
la ciudad y sus arrabales [los motivos no es seguro que se deban a austracismo] (caja 5557, f. 345).

ANEXO 3

PERSONAS CON BIENES SECUESTRADOS Y NOTICIAS SOBRE LA GESTIÓN DE LOS MISMOS

[El asterisco al final de un nombre indica que también aparecen en el listado del anexo 4]

\section{Bienes del señorío de Caladrones}

El 26-8-1709 la Junta concedió a don Miguel Antonio de Arostegui, señor de Isdes, vecino de Benabarre, 836 sueldos del secuestro de don Antonio Bardaxí y Arén, señor de Caladrones por pensiones de censales. Fianza Medardo Viu, vecino de Benabarre (caja 5557, f. 413).

\section{Bienes del barón de Alcalá}

En 1709 se mencionan como secuestrados los bienes de don Antonio de Naya, barón de Alcalá y don Martín de Naya, su hijo (caja 5557, f. 349).

El 4-2-1710 el Hospital de Gracia recibió de la Junta 103 libras de los bienes del ausente como resto del pago de 1.000 doblones de a dos escudos de oro que concedió el rey por una vez sobre confiscaciones. Lo certifica don Antonio de Orbegozo y Landaeta, contador de la superintendencia y de la intervención de la Junta (caja 5557, f. 488).

\section{Bienes de la baronía de Grañén, del estado de Villahermosa}

El 26-2-1708 Francisco Burnía, vecino de Grañén, se hizo fianza de don José Tena y Panzano, nombrado por la Junta administrador de la baronía (caja 5557, f. 69).

\section{Bienes de la baronía de Purroy}

El 10-11-1707 Juan Antonio de Roda, vecino y ciudadano de Calatayud, dejó constancia de que la Junta le había nombrado, a petición propia, administrador de los bienes del barón en el lugar de Purroy. Como fianza presentó a don Anastasio de Cabañas y Abarca, vecino de Zaragoza (caja 5557, ff. 17r-18v).

El 13-3-1708 Francisco Estadilla arrendó a Gerónimo Lostau y Mendoza, maestro carpintero, todos los campos, viñas, olivares y torres del ausente en los barrios y términos de la ciudad por 1 año, desde Navidad de 1707, por 100 libras. Fianza: don Jorge de San Martín (caja 5557, ff. 78r-79v).

El 9-12-1708 Jacinto Castel, maestro cirujano, se hizo fianza de Alonso Martín, maestro cerero y confitero, por haber recibido de la Junta 78 libras 4 sueldos 9 dineros del ausente debidos a recados de su botiga (caja 5557, f. 168).

El 2-2-1710 Gerónimo Lostau y Mendoza, maestro carpintero y vecino de Zaragoza, recibió de la Junta 75 libras 11 sueldos de los bienes del ausente por trabajos que le hizo (caja 5557, f. 485). 
El 6-3-1710 el cabildo de la Seo recibió de la Junta 10 libras 16 sueldos 2 dineros por décimas de uvas de 1705 que debía la baronía (caja 5557, f. 512).

\section{Bienes de la baronía de Torrellas y Antillón*}

El 4-1-1708 Martín Maza de Lizana y don Juan Domingo Pelegrín, vecinos de Zaragoza, nombrados por la Junta administradores de dichas baronias, que estaban en litigio entre don José de Bardaxí Fernández de Heredia y don Jorge de Híjar y consortes, presentaron como fianzas a José Collantes, José Ezquerra y José Boira, vecinos de Zaragoza (caja 5557, ff. 32r-33v y 34r-35v).

En 1708 se otorgaron 7 ápocas o cartas de pago de pensiones de censales pagados. Siguen como administradores Maza de Lizana y Pelegrín (caja 5557).

El 7-5-1709 don Juan Pelegrín y don Martín Maza de Lizana, vecinos de Zaragoza, administradores de los secuestros de las baronías de Antillón y Torrellas y del molino y derechos existentes en Naval, perteneciente a los señores de esta villa, arrendaron a Pascual Bueno, vecino de Zaragoza, el molino harinero de Naval y los edificios y otros bienes de los señores de la villa por 3 años, desde el 1 de junio de 1709, por 363 libras/año. Fiador: don Miguel Ric y Veyán, residente en Zaragoza (caja 5557, ff. 390r391v).

En 1709 se dieron 5 ápocas o cartas de pago de pensiones de censales (caja $5557)$.

E1 24-6-1710 Roque Antonio Núñez recibió de la Junta 15 libras de los bienes de la baronía por la redacción de las cartas de pago a los censalistas (caja 5557, f. 581).

En 1710 se otorgaron 8 cartas de pago de pensiones de censales (caja 5557).

\section{Bienes del estado de Plasencia}

El 6-11-1707 Ignacio del Corral, gobernador de este estado por la Junta de Secuestros, arrendó a Manuel Secano 2/4 de las hierbas de Caulón, que tenía Pedro Benedid y Delgado, por 1 año, desde Santa Cruz de mayo de 1707, por 170 libras (caja 5557 , ff. $9 \mathrm{r}-10 \mathrm{v}$ ).

El 8-10-1708 don Ignacio del Corral, administrador de este estado, arrendó a Alejandro Iturralde, mercader vecino de Zaragoza, las hierbas de Caulón y abrevaderos, sitos en Plasencia, por 1 año, desde Santa Cruz de mayo de 1708, por 430 libras (caja 5557, ff. 150r-151r).

En 1708 se otorgaron 75 ápocas o cartas de pago de pensiones de censales (caja 5557).

En 1709 se otorgaron 17 ápocas o cartas de pago de pensiones de censales (caja 5557).

En 1710 se otorgaron 21 cartas de pago de pensiones de censales (caja 5557).

En 1710 administraba este estado el Tribunal del Santo Oficio de Aragón, cuyo receptor era el presbítero don Benito Sánchez (caja 5557).

En 1710 se redactaron 2 cartas de pago de pensiones de censales (caja 5557).

En 1711 aparece el mismo administrador (caja 5558). 
En 1711 se redactaron 8 ápocas o cartas de pago de pensiones de censales. Una carta de pago más la firma el propio notario por los honorarios debidos a las certificaciones que ha hecho durante el año a los censalistas del estado de Plasencia (caja 5558).

En 1712 el administrador de las rentas del Tribunal era don Pedro Muñoz, y abonó pensiones por medio de 54 cartas de pago (caja 5558).

En 1713, el mismo administrador abonó pensiones a 72 (caja 5558).

En 1714, el mismo administrador abonó pensiones a 45 (caja 5558).

En 1715, el mismo administrador abonó pensiones a 43 (caja 5558).

En 1716, el mismo administrador abonó pensiones a 45 (caja 5558).

\section{Bienes del conde de Elda*}

En 1709 la Junta libró sobre estos bienes 80 cahíces de trigo para que pudieran sembrar los vecinos de Candasnos por concesión del rey, a devolver en septiembre de 1710 (caja 5557, ff. 420r-423v).

En 1709 al menos, don Juan Domeco de Jarauta, vecino de Malón, era el administrador de los granos producidos en los bienes secuestrados del conde. Aparecen 5 cartas de pago de pensiones de censales (caja 5557).

\section{Bienes del condado de Fuentes y marquesado de Mora*}

En 1708 se otorgaron 2 cartas de pago de pensiones de censales (caja 5557).

\section{Bienes del conde de Montoro}

El 3-9-1708 Juan de Sobrecasas se hizo fianza de don Antonio de Puidor Fila, administrador de la hacienda del conde de Montoro, su tío, en Alcañiz y Montoro, debiendo obtener en dos meses la lista de tales bienes en Montoro, que no aparecían en la real cédula (caja 5557, f. 144).

\section{Bienes del condado de Sástago}

E1 1-2-1708 doña Josefa Mauleón y Villava, viuda y vecina de Zaragoza, recibió de la Junta 100 escudos que le debía la casa de Sástago por la renta anual de una casa arrendada en la plazuela del Carbón. Fianza: don Manuel de Mauleón (caja 5557, f. 47).

El 5-11-1708 Juan de la Ortiga se hizo fianza de Juan Francisco Lizarraga, que había pedido de los bienes del ausente 701 libras 5 sueldos por una deuda de una consignación. Se le pagó con efectos de Fuencalderas y baronía de Escuer, siendo administrador de esta última don Pedro Apaolaza (caja 5557, f. 160).

En 1708 se otorgaron 73 cartas de pago de pensiones de censales. El administrador de dicho estado era don Pedro Apaolaza (caja 5557).

E1 24-1-1709 Juan Francisco Lizarraga dio poder para exigir a los administradores de Fuencalderas y baronía de Escuer 701 libras 5 sueldos 2 dineros que le había consignado la Junta y que eran el resto de 1.254 libras 1 sueldo 2 dineros que le consignó el conde de Sástago (caja 5557, f. 344).

En 1709 se otorgó l carta de pago de pensiones de censales (caja 5557). 
En 1710 se otorgaron 12 cartas de pago de pensiones de censales (caja 5557).

En 1710 lo administraba el conde de Peralada, aunque ejercía don Pedro Apaolaza (caja 5557, f. 547).

El 15-4-1713 Alejandro Audina, presbítero y residente de Zaragoza, como procurador de don José de Córdoba y Alagón, residente en Madrid, dio procura a su vez a Pedro Pueyo, maestro platero de Zaragoza, para que reclamase 1.500 escudos de plata al año de los estados de Sástago y Pina, que debía percibir el principal (caja 5558, f. $155)$.

\section{Bienes del marquesado de Ariño}

El 7-4-1709 llegaron a un acuerdo don José Carrillo y doña María Josefa de Pomar, condes de Montemar, residentes en Zaragoza, por una parte, y don Dionisio de Pomar y Foncillas y doña Paula Tudela y Virto, vecinos de Zaragoza, por otra, ya que existían varios pleitos entre los Pomar ante la vieja audiencia y la extinta corte del Justicia por la sucesión del marquesado de Ariño y otros bienes secuestrados. Por este acuerdo pasó el título a don Dionisio de Pomar (caja 5557, ff. 373r-378v).

\section{Bienes del marqués de Castropinós}

El 15-1-1708 José de Baldellou y Mateo se hizo fianza del monasterio de Nuestra Señora de Trasobares del Císter por haber recibido 35 cahíces de trigo del marqués ausente, en Pedrola (caja 5557, f. 40).

El 8-5-1710 doña Úrsula de Aragón Borja, religiosa del convento de Santa Inés, recibió de la Junta 112 libras 6 sueldos por porciones que doña María Inés de Carvajal, ya difunta, mujer del marqués de Castropinós, ausente, llevó al matrimonio y entonces pertenecían a la monja (caja 5557, f. 548).

El 12-5-1710 la Junta recibió de los conservadores de la concordia de censalistas del marquesado de Camarasa y condado de Ricla 35 libras por pensiones de un censal que pertenecía al marqués de Castropinós (caja 5557, f. 551).

El 12-5-1710 la Junta recibió de don Vicente Ximénez de Bagués, administrador del condado de Luna, 77 libras 6 sueldos por pensiones de un censal que pertenecía al marqués de Castropinós (caja 5557, f. 552).

\section{Bienes del marqués de Coscojuela}

El 2-12-1707 don Gaspar de Segovia, comisario nombrado por la Junta, arrendó al conde de Robres, residente en Huesca, unas casas sitas en la ciudad, calle Mayor, que eran del marqués, por 1 año, desde esta fecha y por 25 libras (caja 5557, f. 27).

El 2-8-1708 Martín Bolea, vecino de Fañanás, Félix Boned, vecino de Alcalá del Obispo, Lorenzo Viñuales, vecino de Erla y Antonio Catalán, vecino de Novales, presos en Zaragoza y arrabales por estar acusados de talar el monte y carrascal de Argavieso, del ausente, dieron fianzas para poder ir a cosechar a sus casas (caja 5557, ff. $136 \mathrm{r}-137 \mathrm{v})$.

El 3-11-1708 Juan Francisco Sobrecasas arrendó a Juan de la Cambra, vecino de Juslibol, las tierras y olivares del ausente sitas en Pasaderas por 3 años, desde el 
1-11-1708 por 10 cahíces/año. Fianza: José de Mur, vecino de Juslibol (caja 5557, ff. $156 \mathrm{r}-157 \mathrm{v})$.

En 1708 se dieron 2 cartas de pago de pensiones de censales (caja 5557).

El 5-5-1709 Juan Francisco Sobrecasas arrendó a Juan Cerdán y su mujer Ana de Aína, vecinos de Casetas, el mesón de las Casetas, perteneciente al marqués, por 1 año, desde san Miguel de septiembre de 1708, por 33 libras/año (caja 5557, f. 387).

El 26-10-1709 Bruno Benavente, Martín del Campo, Pedro Lombardía y Bernardo Laborda, vecinos de san Mateo de Gállego, se obligaron a pagar cantidades a la Junta por bienes que tenían del marqués, y también al Hospital de Gracia, al que se le habían adjudicado parte de dichos bienes (caja 5557, ff. 426r-427v).

El 26-11-1709 Bartolomé Benito, vecino de Marlofa, se obligó a pagar a la Junta 21 cahíces 2 fanegas y 9 almudes de trigo, mitad en 1710 y mitad en 1711 por la renta que debía de un quiñón del marqués, arrendado en las Casetas (caja 5557, f. 435).

En 1709 se dio 1 carta de pago de pensiones de censales (caja 5557).

El 8-3-1710 doña Teresa de Moncayo, religiosa del santo Sepulcro, recibió de don Bartolomé Sodeto, mayordomo del Hospital de Gracia, como administrador de este estado, 40 libras por la pensión de un violario (caja 5557, f. 514).

El 29-6-1710 el comendador de san Juan de Barbastro recibió de los bienes del ausente 200 libras [no dice el motivo] (caja 5557, f. 587).

En 1710 se otorgaron 10 cartas de pago de pensiones de censales (caja 5557).

En 1711 aparece como administrador de los bienes el Hospital de Gracia de Zaragoza. El administrador de dicho hospital era Juan de Alfranca, vecino de Zaragoza. En este año se firmaron 4 cartas de pago de pensiones de censales y 1 por la renta de un violario (caja 5558).

En 1712 se certificaron 20 (caja 5558).

En 1713 se certificó 1 (caja 5558).

En 1714 se certificó l (caja 5558).

En 1716 se certificó uno. Siempre Juan de Alfranca actuó como administrador (caja 5558).

\section{Bienes del ducado de Híjar}

El 1-8-1708 mosén Diego Losilla, presbítero y beneficiado de la parroquia de Hijar, tomó a su cargo el pago de 1.406 libras que restaban de las 2.000 en que se obligaron en 1702 por comanda su padre Miguel Losilla y su tío Diego Losilla, infanzones de Hijar, a favor del duque de Híjar. En la fecha de este acto el derecho se había transferido al licenciado don Jorge Nadal, racionero del Pilar (caja 5557, f. 135).

\section{Bienes de Miguel de Ágreda y Gertrudis Teresa, vecinos de Alpartir*}

El 14-11-1707 Pedro de Ágreda, vecino de Alpartir, dio poder a Antonio del Molino, procurador ante la chancillería, para que ante la Junta pidiera satisfacción de sus derechos en los bienes secuestrados a sus hermanos (caja 5557, f. 20). 
El 1-1-1708 la Junta nombró a Pedro de Ágreda administrador de los bienes de sus hermanos hasta que se hiciera la partición. Fianzas: Diego Peña, platero y Bartolomé Sánchez, organero, vecinos de Zaragoza (caja 5557, ff. 30r-31v).

\section{Bienes de Juan de Aínsa, vecino de Sos}

El 13-2-1708 Juan de la Ortiga se obligó a pagar en marzo 175 libras que los pupilos del ausente debían a S.M. por el secuestro de bienes, por lo que eran apremiados por la Justicia de la villa (caja 5557, f. 57).

\section{Bienes de don Marcelo de Aínsa*}

El 9-7-1709 la Junta entregó a Pedro Dufraise, vecino de Zaragoza, 85 libras 12 sueldos de los bienes del ausente. Fianza: José Ribera Maza de Lizana (caja 5557, f. 403).

El 16-3-1710 la Junta entregó al capellán Diego Mediavilla 15 libras 7 sueldos 9 dineros por pensiones de un censal. Fianza: Francisco Mediavilla, vecino de Zaragoza (caja 5557, f. 519).

E1 10-4-1710 una capellanía en san Miguel recibió de la Junta 15 libras 7 sueldos 9 dineros de los bienes del ausente (caja 5557, f. 538).

\section{Bienes de Ignacio Alcaine*}

El 4-4-1708 Francisco Estadilla arrendó a Bernardo Salvador todas las viñas y campos sitos en Zaragoza y barrios del ausente por 1 año, desde Navidad de 1707 por 16 libras. Fianza: Jaime Fandos, vecino de Zaragoza (caja 5557, ff. 97r-98v).

El 25-1-1709 Pedro Salcedo era fianza de la iglesia de san Cayetano por 30 libras de pensiones de censales recibidas del secuestro de Alcaine (caja 5557, f. 347).

\section{Bienes de Tomás Alcalá*}

El 4-4-1708 Francisco Estadilla arrendó a José Laborda todas las viñas sitas en Zaragoza y barrios del ausente por 1 año, desde Navidad de 1707 por 100 reales. Fianza: Gregorio Benedid (caja 5557, ff. 99r-100v).

\section{Bienes de don Pedro Andrés*}

El 5-3-1708 Francisco Estadilla arrendó a Andrés Murillo los campos, viñas y olivares del ausente por 1 año desde Navidad de 1707 por 70 pesos de a ocho reales de plata. Fianza: don Juan Mauleón, infanzón, vecino de Zaragoza (caja 5557, ff. 74r$75 \mathrm{v})$.

El 13-3-1708 Miguel Martín se hizo fianza de la parroquia de san Felipe por haber recibido de la Junta 200 sueldos de pensiones contra el ausente (caja 5557, f. 82).

E1 22-6-1708 la Junta pagó a Gregorio Oporto, vecino de Zaragoza, 70 libras 16 sueldos 11 dineros de los bienes del ausente debidos por varios recados. Fianza: don Francisco Medrano (caja 5557, f. 115).

El 14-1-1709 Juan Francisco Sobrecasas recibió de don José Vidania 10 libras por los réditos de diez años de un treudo perpetuo del ausente sito sobre un huerto en el término del Gállego (caja 5557, f. 335). 
E1 27-12-1709 Juan Francisco Sobrecasas arrendó a José de Rodas, labrador de Zaragoza, todas las viñas, campos, olivares y tierras del ausente por 3 años, a contar desde el 1 de enero de 1710, por 100 libras/año. Fianza: don Miguel Ramón Correjas (caja 5557, ff. 448r-449v).

El 19-7-1710 un beneficiado de la parroquia de Santiago recibió de la Junta 21 libras del secuestro del ausente (caja 5557, f. 599).

\section{Bienes de don Gerónimo Antón*}

El 5-2-1708 la Junta pagó a don Pedro Lamberto la Viña 300 libras (en trigo) que le debía el ausente. Fianza: Juan de la Viña (caja 5557, ff. 48r-49v).

El 9-2-1708 Francisco Estadilla y Juan Francisco Sobrecasas arrendaron a Miguel de Guadalajara Ximénez de Cenarbe los campos, viñas, olivares y la bodega de vino anexa a las casas principales del ausente por 3 años, desde Todos los Santos de 1707, por 80 libras/año. Fianza: Salvador de Miranda (caja 5557, ff. 52r-53v).

El 20-2-1710 el cabildo de la Seo recibió de la Junta 17 libras 2 sueldos por las décimas de unas uvas producidas en 1707 en viñas del ausente (caja 5557, f. 500).

\section{Bienes de Domingo Beltrán*}

E1 22-4-1708 Pedro Borderas, francés residente en Zaragoza, se opuso al secuestro de bienes de Beltrán reclamando 35 libras de una parte de una partida de tocino que le vendió y le debía. Fianza: José Castillo Larroy, vecino de Zaragoza (caja 5557, f. 104).

E1 19-2-1709 Juan Francisco Sobrecasas arrendó a Francisco Gabín, maestro tafetanero, los campos, viñas y olivares del ausente por 3 años, desde el 1 de enero de 1709 , por 10 libras/año (caja 5557, ff. 367r-368v).

\section{Bienes de Pedro Benedid}

El 10-2-1708 Juan Francisco Sobrecasas arrendó a Juan José Casamayor, mercader y vecino de Zaragoza, las casas en la calle del Pilar que lindan con la de Miguel Correxas, que eran del ausente, por 6 años, desde el 1 de enero de 1708, por 30 libras/ año. Fianza: Juan de la Coma, mercader y vecino de Zaragoza (caja 5557, ff. 54r55v).

El 17-2-1708 Francisco Estadilla arrendó a Gerónimo Secano tres viñas y un olivar del ausente por 1 año desde Navidad de 1707 por 25 libras. Fianza: Pedro Secano, mercader (caja 5557, ff. 60r-61v).

El 20-6-1709 Gerónimo Secano, vecino de Zaragoza y tutor de Francisco Arín, menor de 25 años, nombró procurador a Ignacio del Corral y Antonio de Urrea para que pidieran a la Junta 14.000 escudos de los bienes del ausente debidos por testamentos y capitulaciones matrimoniales (caja 5557, f. 399).

El 8-11-1709 Juan Francisco Sobrecasas arrendó a Pedro Secano unas casas sitas en Zaragoza, calle de las Armas, y unos campos, viñas y olivares del ausente por I año, las primeras desde San Juan de junio de 1709 y lo demás desde el 1 de enero de 1709 , por 60 libras/año (caja 5557, f. 433). 
E1 22-3-1710 Pabla Secano, mujer del ausente, recibió de la Junta 50 libras por derechos que le correspondían (caja 5557, f. 524).

El 25-5-1710 don Juan Antonio de Naya, relator de la real chancillería, recibió de la Junta 2 doblones de a dos escudos de oro del secuestro por el trabajo de hacer la relación de antes y diligencias en su secuestro (caja 5557, f. 564).

\section{Bienes de don José Borao*}

El 13-3-1708 Miguel Martín, maestro torcedor de seda, se hizo fianza de la parroquia de San Felipe por haber recibido de la Junta 100 libras por treudos contra el ausente (caja 5557, f. 80).

El 21-1-1709 Martín de Michelena se presenta como fianza del presbítero don Diego Pedrosa, de la parroquia de San Felipe, para recibir 44 libras del ausente (caja 5557, f. 339).

El 23-5-1709 Francisco Aldover recibió del secuestro del ausente 30 libras, presentando como fianza a José Iñareta, maestro sastre, vecino de Zaragoza (caja 5557, f. 395).

El 27-1-1710 Francisco Alcober recibió de la Junta 30 libras que le debía el ausente por un crédito (caja 5557, f. 483).

\section{Bienes de Pedro Bulosa*}

El 17-2-1708 Francisco Estadilla arrendó a Pedro Laborda, labrador, los campos, viñas, olivares y abejares del ausente, pudiendo pagar las alfardas con un censal de Bulosa, por 1 año, desde Navidad de 1707, por 105 libras. Fianza: Gil Miguel Cavero (caja 5557, ff. 62r-63v).

El 10-5-1708 don Domingo Gascón, infanzón, pidió 275 libras de los bienes del ausente. La Junta accedió presentando fianza, que fue Bartolomé de Campos (caja 5557, f. 106).

E1 13-2-1709 Juan Francisco Sobrecasas arrendó a Gil Miguel y Cavero los campos, viñas, olivares y un abejar de cuatro vasos del ausente por 3 años, desde el 1 de enero de 1709, por 30 libras/año (caja 5557, f. 364).

\section{Bienes de don Pedro Butrón, vecino de Calatayud*}

El 5-9-1708 Lorenzo de Fraguas, vecino de Calatayud, apoderó a Ignacio del Corral y Antonio de Urrea para que pidieran en la Junta 59 escudos del ausente, vecino de Calatayud (caja 5557, f. 147).

\section{Bienes de Jaime Juan Camprodón, vecino de Fraga}

El 20-11-1708 la Junta pagó 20 libras a los parroquianos de San Pablo y San Miguel de Fraga por pensiones de censales del ausente. Fianza: don Miguel Bodón, vecino de Fraga (caja 5557, f. 161).

\section{Bienes de Félix Castillo*}

E1 13-3-1708 Miguel Martín se hizo fianza de la parroquia de San Felipe por haber recibido 400 sueldos de pensiones contra el ausente (caja 5557, f. 81 ). 
El 13-2-1709 Juan Francisco Sobrecasas arrendó a Manuel Soler los campos, viñas y olivares del ausente por 3 años, desde el 1 de enero del corriente, por 60 libras/ año (caja 5557, f. 356).

El 8-7-1710 don Francisco Vidania recibió de la Junta 7 libras del secuestro del ausente [no explica el motivo] (caja 5557, f. 593).

\section{Bienes de Antonio Colea, vecino de Fraga}

E1 21-11-1708 don Miguel Bodón se hizo fianza de los parroquianos de San Pedro y San Miguel de Fraga por haber recibido de la Junta 70 sueldos de pensiones de censal de los bienes del ausente (caja 5557, f. 164).

\section{Bienes de Nicolás la Coma, vecino de Huesca*}

El 14-12-1709 la Junta pagó al licenciado don Miguel Laín y Binacua, administrador de las rentas del seminario de Huesca, 200 libras de los bienes del ausente. Fianza: Domingo Ranceta, vecino de Zaragoza (caja 5557, f. 441).

\section{Bienes de Pedro Delgado}

E1 8-7-1709 la Junta permitió a Pedro Delgado que administrase sus bienes y los de su madre, María Colón, en principio secuestrados. Fianza: don Miguel Antonio de Arostegui, vecino de Benabarre (caja 5557, f. 402).

\section{Bienes de don José de Eril y Ortiz}

El 2-5-1709 José de Baldellou, vecino de Zaragoza, se hizo fianza de don Pedro Bardaxí y Ascón, vecino de Zaragoza, que recibió por la Junta, de los bienes del ausente, habitante en Barcelona, 452 sueldos 9 dineros de pensiones de censales (caja 5557, f. 384).

\section{Bienes de don Juan Escoto*}

El 22-4-1709 Juan Francisco Sobrecasas arrendó a José Mombiela, vecino de Zaragoza, una torre con huerta en la partida de Roseque, del ausente, por 1 año, desde San Juan de junio, por 30 libras/año (caja 5557, f. 382).

\section{Bienes de don Esteban Esmir*}

El 24-3-1708 José de Muro se hizo fianza para la parroquia de la villa de Épila por haber recibido de la Junta 420 sueldos por pensiones contra el ausente (caja 5557, f. 90).

El 18-2-1710 don Manuel de Santos, abogado y vecino de Zaragoza, recibió de la Junta 8 libras de los bienes del ausente por hacer la relación de las pretensiones y otras diligencias en el pleito de este secuestro (caja 5557, f. 498).

\section{Bienes de don Francisco Esmir*}

El 4-7-1708 Esperanza López Rueda, vecina de Zaragoza, nombró procurador a Francisco Antonio Ondeano para que ante la Junta expusiera que de los bienes del ausente debían pagarle un real al día de por vida porque así lo fijó en su testamento don 
Luis Jacinto Esmir y Casanate, de quien era heredero don Francisco, que no le pagaba además hace 3 años (caja 5557, f. 120).

El 16-1-1709 Juan Francisco Sobrecasas arrendó a Juan Durán, vecino de Zaragoza, unas casas grandes sitas en la calle Mayor, junto al Arbellón, por seis años, a contar desde el 1 de enero presente por 80 libras/año (caja 5557, ff. 336r-337r).

El 17-1-1710 Juan Francisco Sobrecasas arrendó a Pedro Martínez, vecino de Zaragoza, las viñas, campos, olivares, torres y demás del ausente por 1 año, desde el 1 de enero, por 100 libras. Fianza: don Agustín Bosque, vecino de Zaragoza (caja 5557, ff. $479 \mathrm{r}-480 \mathrm{v})$.

El 22-2-1710 don Miguel Ramón Correxas, vecino de Zaragoza, recibió de la Junta 100 libras de bienes del ausente que se le habían adjudicado por real cédula (caja 5557, f. 505).

\section{Bienes de don Pedro Español, vecino de Alagón}

E1 15-12-1709 la Junta entregó a los procuradores testamentarios de Pedro Alamán 1.678 reales de plata de los bienes del ausente por una deuda del mismo [se alude también a los bienes secuestrados de Sebastián Barbod, en Épila] (caja 5557, f. 443).

E1 16-12-1709 la Junta entregó al convento del Santo Sepulcro 20 libras 5 sueldos por la pensión de un treudo de 3 cahíces de trigo/año contra los bienes del ausente (caja 5557, f. 445).

\section{Bienes de José Espés}

El 20-7-1708 Juan Francisco Sobrecasas arrendó a Manuel Buil, labrador, una torre y un huerto del ausente en el Rabal por 6 años, desde san Juan de 1708, por 60 libras. Fianza: Félix Casales, labrador de Zaragoza (caja 5557, ff. 124r-125v).

\section{Bienes de don Miguel de Espinal}

El 8-11-1707 don Manuel Espinal y don José Manuel Sánchez del Castellar, vecinos de Zaragoza, se hicieron fianzas de doña Josefa Gertrudis Bueno, mujer del ausente, a quien la Junta permitía recoger la cosecha de uvas de ese año y se le entregaban también el trigo y la cebada secuestrados en el lugar de Gallur, que eran bienes de su marido, si había fianzas que dijesen exactamente lo obtenido (caja 5557, f. 16).

\section{Bienes de don Agustín Estanga*}

El 18-2-1708 Francisco Estadilla arrendó a don Blas López de Zuloeta los campos, viñas y olivares con la torre que estaba en la viña de Valjunquera, del ausente, por 1 año, desde Navidad de 1707 por 90 libras. Fianza: Antonio Andilla (caja 5557, ff. $66 \mathrm{r}-67 \mathrm{v})$.

El 13-2-1709 Juan Francisco Sobrecasas arrendó a don Blas Zuloeta, vecino de Zaragoza, los campos, viñas y olivares del ausente por 3 años, desde el 1 de enero de 1709, por 90 libras/año (caja 5557, ff. 362r-363v). 


\section{Bienes de Antonio Matías de la Fuente, vecino de Alagón}

El 25-2-1709 don Juan Gerónimo de Blancas, corregidor de Zaragoza, tras presentar real cédula de 15 de enero de 1709 por la que se le adjudicaba la hacienda del ausente, nombró procurador para recibirla en Daroca y Murero a don Martín de Michelena (caja 5557, f. 369).

\section{Bienes de don José de Fuentes, vecino de Ateca}

El 4 y 5-9-1708 Lorenzo de Fraguas, vecino de Calatayud apoderó a don Ignacio del Corral y don Antonio de Urrea para que pidieran en la Junta 48 escudos 16 sueldos de los bienes del ausente por un préstamo (caja 5557, f. 146).

\section{Bienes de Gerónimo Garay, vecino de La Almunia*}

E1 20 y 28-2-1708 los jurados de La Almunia presentaron como fianza, por haber recibido de la Junta 134 libras 9 sueldos que tenía en comanda el ausente, a don Miguel López Generés, vecino de La Almunia, y días después a don Lorenzo López Generés (caja 5557, ff. 68 y 70 ).

En 1709 la Junta libró a don Jaime Mínguez, vecino de La Almunia y administrador de los bienes de Garay y otros, una orden para entregar 10 cahíces de trigo de siembra al apoderado del alcalde y regidores de Candasnos, que los habían recibido del rey (caja 5557, ff. 420r-423v).

El 13-2-1710 la Junta concedió la viudedad de los bienes secuestrados a Gerónimo Garay menor, ausente, a Antonia Navarro, su mujer. Fianza: Pascual de Liarte, maestro de coches, vecino de Zaragoza (caja 5557, f. 494).

El 14-2-1710 Antonia Navarro recibió de la Junta 97 libras como parte de las 200 libras que debía recibir del secuestro de Gerónimo Garay menor, y que llevó al matrimonio (caja 5557, f. 496).

\section{Bienes de Martín Garay, vecino de La Almunia}

El 4-12-1709 la Junta entregó a Miguel García, labrador, vecino de Épila, 900 sueldos por una comanda que debía el ausente. Fianza: Juan Jubera, vecino de Zaragoza (caja 5557, f. 436).

El 24-1-1710 Martín Fabro, vecino de Épila y apoderado de Miguel García y Ana Gil, vecinos de Épila, recibió de la Junta 45 libras de los bienes del ausente por una comanda (caja 5557, f. 481).

El 13-2-1710 la Junta otorgó la viudedad de los bienes secuestrados al ausente a María de Hacha. Fianza: Diego de Hasta, vecino de Zaragoza (caja 5557, f. 492).

El 13-2-1710 Bernardo de Hacha, labrador de La Almunia y con poder de su hija María, recibió de la Junta 78 libras 4 sueldos como parte del pago de 150 libras que debía percibir del secuestro por lo llevado al matrimonio por la hija (caja 5557, f. 493).

El 1-6-1710 María de Hacha, vecina de La Almunia y viuda de Martín Garay, recibió de la Junta 33 libras 7 sueldos 7 dineros como fin de pago del importe de 17 cahíces 6 fanegas de trigo que debía recibir del secuestro por la viudedad (caja 5557, f. 572). 


\section{Bienes de José Matías García, vecino de Calatorao*}

El 2-7-1708 la Junta nombró administrador de los bienes del ausente a José Gil de Banero, vecino de Calatorao y residente en Zaragoza. Fianza: Tiburcio Ucenda, vecino de Calatorao (caja 5557, f. 119).

\section{Bienes de José Félix García Lorente}

E1 9-1-1709 Francisco de Lizarraga se presentó como fianza de la cofradía de Nuestra Señora y Todos los Santos de Zaragoza, que pedía 24 libras de los bienes de Lorente, máxime al concederse el disfrute de los bienes del huido a su mujer, doña Josefa María Fernández, que iba a irse a Cataluña (caja 5557, f. 334).

\section{Bienes de don Francisco Gazo*}

El 27-3-1708 Francisco Estadilla arrendó a Miguel de Latas, maestro armero, todos los campos y viñas del ausente por 1 año desde Navidad de 1707 por 20 libras. Fianza: don Juan Arnal (caja 5557, ff. 95r-96v).

El 6-5-1709 Juan Francisco Sobrecasas arrendó a Juan Silvestre López los campos, viñas, olivares y casas en Pastriz del ausente por 2 años, desde el 1 de enero de 1709, por 60 libras/año. Fianza: Juan Antonio Bernal, vecino de Zaragoza (caja 5557. ff. $388 \mathrm{r}-389 \mathrm{v}$ ).

\section{Bienes de don Pedro de Gracia y doña Juana María Duato, vecinos de Fraga}

E1 7-6-1708 la Junta pagó al obispo de Lérida 90 libras por pensiones de censales contra los bienes de doña Juana. Fianza: Juan Escuder, vecino de Zaragoza (caja 5557, f. 112 ).

E1 9-7-1709 la Junta entregó a Pedro Dufraise 222 libras 7 sueldos 6 dineros de los bienes del ausente y de su mujer doña Juana María Duaso. Fianza: José Ribera Maza de Lizana (caja 5557, f. 404).

E1 26-10-1709 la Junta ordenó pagar a mosen Antonio Tello, vecino y presbítero de Fraga 1.062 libras que le debían el ausente y su mujer. Fianza: Pedro Millán, vecino del lugar de las Parras (caja 5557, f. 428).

E1 8-11-1709 Juan Francisco Sobrecasas arrendó a don Manuel Xilbert de Granja Fernández y Heredia, vecino de Zaragoza, todos los bienes doña Juana María Duato, viuda del ausente, vecino de Fraga, sitos en Fraga, Belber, Almudafar, Oso y Chalamera por 2 años, desde San Miguel de septiembre de 1709, por 345 libras/año. Fianza: don Vicente Francés y Canales, vecino de Zaragoza (caja 5557, ff. 431r-432v).

\section{Bienes de don Francisco Ibáñez*}

El 10-2-1709 Juan Francisco Sobrecasas arrendó a don Lorenzo Ibáñez de Aoíz las casas, campos, viñas y olivares del ausente por 3 años, desde el 1 de enero de 1709 y por 30 libras/año (caja 5557, ff. 354r-355v).

\section{Bienes de don Gabriel de Irazábal*}

El 27-12-1709 Juan Francisco Sobrecasas arrendó a José de Rodas, labrador de Zaragoza, las viñas, campos, olivares y tierras en el término de Miralbueno del ausente 
por 3 años, desde el 1 de enero de 1710, por 25 libras/año. Fianza: don Miguel Ramón Correjas, vecino de Zaragoza (caja 5557, ff. 446r-447v).

El 5-7-1710 sor Josefa de Irazábal, del convento de la Encarnación de Zaragoza, recibió 25 libras de la Junta por la pensión de un violario sobre los bienes del ausente (caja 5557, f. 591).

\section{Bienes de José Jiménez, vecino de Tauste}

El 8-8-1709 la Junta entregó a Martín de Iturriaga, vecino de Tudela, 55 libras 4 sueldos de los bienes del ausente. Fianza: Antonio Lapuente, maestro cerero, vecino de Zaragoza (caja 5557, f. 411).

\section{Bienes de Domingo Labarta*}

El 22-4-1708 Francisco Estadilla arrendó a Francisco de Miro una viña y un campo del ausente por 1 año desde Navidad de 1707 por 8 libras. Fianza: José Labarta (caja 5557, ff. 102r-103v).

\section{Bienes de Domingo Laborda*}

El 17-2-1708 Francisco Estadilla arrendó a Gil Cavero los campos, viñas y olivares en la Almotilla del ausente por 1 año, desde Navidad de 1707 por 8 libras. Fianza: Pedro Laborda (caja 5557, ff. 58r-59v).

El 13-2-1709 Juan Francisco Sobrecasas arrendó a Pedro Laborda las viñas, campos y olivares de Domingo Laborda por 3 años, desde el 1 de enero de 1709, por 8 libras/año (caja 5557, ff. 360r-361r).

\section{Bienes de don Bartolomé y don Francisco Lafita*}

E1 31-5-1710 Juan Francisco Sobrecasas arrendó a Alonso Martín, maestro cerero y confitero, las viñas de los ausentes, hermanos, sitas en Zaragoza y en Monzalbarba y un campo en Almozara por 3 años, desde el 1 de enero de 1710 por 50 libras/año (caja 5557 , f. 571).

\section{Bienes de Andrés Lamarca}

El 19-1-1709 Francisco Simón Juárez, vecino de Zaragoza, dio poderes a Francisco Antonio Ondeano para que lo defendiera en la causa criminal pendiente ante la Junta de Secuestros por haber tomado 11 paños de «raz» y otras cosas de Merenciana Clos, mujer del ausente, sin haber informado a dicha Junta (caja 5557, f. 338).

\section{Bienes de don Lucas Laporta*}

El 8-8-1709 Juan Francisco Sobrecasas arrendó unas casas en la calle Mayor (lindantes con las de José Navarro, el conde de Atarés y conde de San Juan el Viejo) a don Juan Manuel de Mauleón como procurador de don Francisco Catalán y Serrano, por 40 libras/año, 50 libras si se incluía la bodega. Fianza: don Manuel de Sola (caja 5557, ff. $408 \mathrm{r}-410 \mathrm{v})$. 
El 7-4-1710 Juan Francisco Sobrecasas recibió del arzobispado de Zaragoza, por manos de su administrador, don Gaspar de Segovia, 189 libras 6 sueldos, por pensiones de un censal del ausente (caja 5557, f. 535).

\section{Bienes de don Luis de Latorre*}

E1 17-7-1709 la Junta dio a Josefa de San Martín, viuda de Juan Pérez, vecina de Daroca, 6.400 sueldos que debía por una comanda el ausente, vecino de Odón, junto con su hijo don José. Fianza: Pedro Hernando Capdevilla (caja 5557, f. 407).

\section{Bienes de don Antonio Luzán, vecino de Zaragoza}

El 16-10-1708 don Luis Clemente, vecino de Huesca, se hizo fianza de don Bernardo Clemente y Abarca, canónigo de la catedral de Huesca, y de don Pedro Clemente y Galbán, residente en ella, para reclamar varias pensiones de censales del ausente (caja 5557, f. 152).

E1 11-12-1709 don Baltasar Barduzal, vecino de Zaragoza, y con poder del marqués del Alcázar, del consejo de Castilla y encargado por el rey de la administración de los bienes secuestrados del ausente, presentó como fianzas a don Antonio de Leiza y Eraso y don José Soriano y Gan, vecinos de Huesca. Además el rey había adjudicado sobre dichos bienes 1.000 escudos de una vez para don José Antonio Torrejón (caja 5557 , ff. 437r-440v).

\section{Bienes de José Mallada}

El 25-3-1708 Francisco Estadilla arrendó a Salvador Franco todos los campos, viñas y olivares sitos en Zaragoza y barrios del ausente por 1 año, desde Navidad de 1707 por 12 libras. Fianza: Juan Franco, su hermano (caja 5557, ff. 91r-92v).

E1 26-10-1708 el colegio agustino de Santo Tomás de Villanueva pidió a la Junta 6 libras 6 sueldos por el resto de una deuda del ausente. Fianza: Juan Francisco Sobrecasas (caja 5557, f. 155).

El 13-2-1709 Juan Francisco Sobrecasas arrendó a Salvador Franco los campos, viñas y olivares del ausente por 3 años, desde el 1 de enero de 1709, por 30 libras/año (caja 5557, ff. 358r-359v).

\section{Bienes de José Manuel*}

El 1-9-1709 don Martín de Ezpeleta, infanzón, vecino de Zaragoza, nombró procurador a Ignacio del Corral porque José Pasamonte, alguacil de la real chancillería, le había demandado pidiendo de los bienes del ausente, que usufructuaba Ezpeleta, 339 libras, 15 sueldos 8 dineros que supuestamente le debía (caja 5557, f. 415).

\section{Bienes de don Vicente Martínez de Luna, vecino de Uncastillo}

El 3-3-1708 el infanzón don Vicente Martínez nombró a Juan Gerónimo Andosilla para que pidiera a la Junta que levantara el secuestro de sus bienes pues durante la rebelión estaba fuera de su casa pero en lugares vecinos, y no salió del reino (caja 5557$, f. 73$)$. 
El 28-4-1709 don José Antonio Torrero y Altarriba y don Pedro Melchor Alegre y Lerma, regidores de Zaragoza y del Hospital de Gracia dieron poder para recibir de la Junta 865 doblones de a dos escudos de oro, que eran el resto de 1.000 doblones que el rey mandó dar a dicho hospital de bienes secuestrados en el reino. Para ello se entregó el ganado mayor secuestrado de Martínez de Luna (caja 5557, f. 383).

\section{Bienes de don Antonio Mendoza}

El 21-3-1708 Francisco Estadilla arrendó a Miguel Claver, labrador de Zaragoza, todos los campos, viñas y olivares del ausente por 1 año desde Navidad de 1707 y por 10 libras. Fianza: Pedro Lamata, labrador (caja 5557, ff. 85r-86v).

E1 17-6-1709 Juan Francisco Sobrecasas arrendó a Pedro Lamata 2 viñas del ausente por 3 años, desde el 1 de enero de 1709, por 50 reales/año (caja 5557, f. 398).

\section{Bienes de don José Mendoza*}

E1 2-9-1708 Francisco Estadilla arrendó a José Lizondo, labrador de Zaragoza, la torre y huerto del ausente, en la adula del lunes del Huerva por 1 año, desde San Juan de 1708, por 13 libras. Fianza: Francisco Álvarez (caja 5557, ff. 142r-143v).

\section{Bienes de Félix Montalbán}

El 27-12-1709 Juan Marzo, vecino de Almonacid de la Cuba y Vicente Lacambra, vecino de Zaragoza, fianzas de José Marco, vecino de Azuara, ejercieron como fianzas de éste para que saliera de la cárcel por no satisfacer sus cuentas sobre bienes secuestrados en Azuara del ausente (una porción de ganado cabrío) (caja 5557, f. 450).

\section{Bienes de Juan Antonio Montes}

El 19-7-1710 la parroquia de San Miguel recibió del secuestro del ausente 15 libras que restaban por los alquileres de un bien [ilegible], en total 45 , si bien se conformó con recibir 30 de los bienes dotales de doña Josefa Cebrián, mujer del ausente (caja 5557, f. 597).

El 22-5-1710 doña Josefa Teresa Cebrián y Pea, domiciliada en Zaragoza, recibió de la Junta 50 libras del secuestro de su marido por la dote (caja 5557, f. 560).

\section{Bienes de Juan Morales*}

El 10-6-1709 Estefanía Gavás, vecina de Zaragoza y mujer del ausente, nombró a un procurador que la defendiera en el pleito del secuestro del marido (caja 5557, f. 397).

\section{Bienes de Antonio Narbión*}

El 2-5-1709 Juan Antonio Lope, vecino de Zaragoza, se hizo fianza de la parroquia de Villa[ilegible], que recibió de la Junta 165 libras de los bienes del ausente por fin de una comanda (caja 5557, f. 386). 


\section{Bienes de doña Teresa de Orera y don Manuel de Orera, su hijo, vecinos de Daroca*}

E1 25-2-1709 don Juan Gerónimo de Blancas, corregidor de Zaragoza, tras presentar real cédula de 15 de enero de 1709 por la que se le adjudicaban los bienes de los Orera, nombró como procurador para recibirlos en Daroca y Murero a don Martín de Michelena (caja 5557, f. 369).

E1 20-2-1710 el capellán de la ermita de N. ${ }^{a}$ S. ${ }^{a}$ de la Laguna recibió de la Junta 50 libras del secuestro de doña Teresa Orera en Murero por consignación hecha en real cédula y es por pensiones de censales (caja 5557, f. 501).

El 7-4-1710 Juan Francisco Sobrecasas recibió de Lucas del Cos, vecino de Zaragoza, 100 libras por el arriendo de la hacienda de los Orera en Monzalbatba y términos. Es el resto del arriendo de 1709 (caja 5557, f. 536).

El 23-5-1710 don Álvaro Aldana y Espinosa, vecino de Zaragoza y relator de la real chancillería recibió de la Junta 3 doblones de a dos escudos de oro del secuestro de los ausentes por el trabajo de hacer los autos del mismo (caja 5557, f. 562).

\section{Bienes de Gerónimo Oset}

[Noticia confusa]. El 27-11-1708 el notario Roque Antonio Núñez, acompañado del portero de la Junta, fueron a la casa de Cristina Betés, viuda de Domingo Bas, maestro tinturero, en la parroquia de Altabás, para embargar los bienes de esa casa, que se creía que eran de Oset, maestro pelaire, ausente, y así pagar los arriendos que debía Cristina de una casa. Ésta alegó que había pagado a Pedro Boyra, maestro tinturero, el arriendo de otra casa, el cual fue llamado, lo confirmó y se mostró dispuesto a poner a disposición de la Junta lo cobrado (caja 5557, f. 165).

\section{Bienes de don José Ozcáriz y Ferrer*}

E1 24-1-1708 Juan Francisco Sobrecasas, vecino de Zaragoza, arrendó a José Briz, maestro carpintero, vecino de Zaragoza, una casa del ausente en calle de los Señales, parroquia de San Lorenzo por 4 años, desde el 1 de enero de 1708 [la cuantía es ilegible]. Fianza: Gregorio Moren, maestro cordonero (caja 5557, ff. 42r-43v).

E1 2-5-1709 Manuel Simón de Sola, vecino de Zaragoza, se hizo fianza de los ejecutores testamentarios de mosen Miguel Lacasa, que recibió de la Junta, de los bienes del ausente, 389 sueldos 4 dineros, así como del capítulo de San Lorenzo, que recibió 91 sueldos 4 dineros por pensiones de censales (caja 5557, f. 385).

E1 9-7-1709 la Junta entregó a Pedro Dufraise, vecino de Zaragoza, 30 libras de los bienes del ausente. Fianza: José Ribera Maza de Lizana (caja 5557, f. 405).

\section{Bienes de Cayetano Pasqual}

El 8-2-1708 Pedro Arrabal, labrador de La Almunia, nombró como procurador a Ignacio del Corral para que pidiera a la Junta que le entregasen 208 arrobas de aceite secuestradas, o su valor, en poder de Jaime Monjón, vecino de La Almunia, con el pretexto de ser del ausente, siendo que dicho aceite era del arrendamiento que los dos hicieron de las décimas de Cabañas, del cabildo del Pilar, de cuyo arriendo se dejaron a 
deber 230 libras. A él le tocaban la mitad, y tenía destinado para ello el valor del aceite (caja 5557, f. 50).

\section{Bienes de José Miguel Pérez de las Aguas*}

El 21-3-1708 Francisco Estadilla arrendó a Miguel Lorente, maestro alarife vecino de Zaragoza, todas las viñas, campos y olivares del ausente por 1 año desde Navidad de 1707, por 20 libras. Fianza: Blas Ximénez, maestro alarife, vecino de Zaragoza (caja 5557 , ff. $87 \mathrm{r}-88 \mathrm{v}$ ).

El 3-3-1709 Juan Francisco Sobrecasas arrendó a José Servisé las viñas del ausente (en realidad cinco viñas y dos majuelos) por 3 años, desde el 1 de enero de 1709, por 25 libras/año (caja 5557, ff. 370r-371v).

\section{Bienes de José Quibus, vecino de Tamarite*}

E1 27-6-1708 la Junta pagó a María del Rey, vecina de Zaragoza, 56 libras 9 sueldos de los bienes del ausente por un albarán con varias compras. Fianza: Pedro José Alamán, mercader de Zaragoza (caja 5557, f. 118).

\section{Bienes de don Manuel de Ribas*}

El 8-1-1708 Francisco Estadilla, administrador por la Junta, arrendó a Juan Francisco Lizarraga los campos, viñas y olivares del ausente por 1 año, desde Navidad de 1707 y por 30 libras (caja 5557, f. 36).

El 24-1-1709 Juan Francisco Sobrecasas recibió de Juan Francisco Lizarraga, vecino de Zaragoza, 30 libras por el arriendo de las viñas, campos y olivares del ausente, cumplido el 31 de diciembre de 1708 (caja 5557, f. 343).

El 22-1-1709 Juan Francisco Sobrecasas arrendó a Juan Francisco Lizarraga, vecino de Zaragoza, viñas, campos y olivares en Zaragoza por 3 años, desde el 1 de enero de 1709 por 51 libras/año (caja 5557, ff. 340r-341v).

El 28-5-1710 José Navarro, maestro cerero y confitero, vecino de Zaragoza, recibió de la Junta del secuestro del ausente 16 libras 11 sueldos 2 dineros por una deuda que le debía (caja 5557, f. 568).

El 14-2-1710 Juan Francisco Sobrecasas recibió de Juan Francisco Lizarraga, vecino de Zaragoza, 51 libras por el arriendo de los campos, viñas y olivares secuestrados del ausente que faltaban de 1709 (caja 5557, f. 495).

\section{Bienes de Gerónimo Félix del Río*}

El 27-4-1708 José de Baldellou se hizo fianza de Pedro Luesma por haber recibido de la Junta 61 libras 9 sueldos 9 dineros del ausente debidos por el herbaje del ganado lanar. Una parte, 47 libras 11 dineros, le correspondían realmente al marqués de Tosos, el resto a Luesma, pero se comprometió a abonarle al marqués (caja 5557, f. 101).

El 27-4-1708 Sebastián Alcoy, maestro sastre vecino de Zaragoza, pidió 40 libras del ausente por varios trabajos hechos. La Junta se los dio presentando fianza, que fue José Alcoy, maestro albañil (caja 5557, f. 105).

El 20-7-1708 José Valdellou y Mateo, vecino de Zaragoza y procurador del monasterio de Santa María de Trasobares, recibió de la Junta 793 libras 4 sueldos 3 
dineros a cuenta de 1.095 asignadas de los bienes del ausente para el ingreso y alimentos de doña Teresa del Río y doña Melchora del Río, hermana e hija respectivamente (caja 5557, f. 123).

\section{Bienes de don Francisco Serra y Ardid}

E1 24-3-1708 José de Muro, vecino de Zaragoza, se hizo fianza por la parroquia de la villa de Épila por haber recibido de la Junta 46 libras 16 sueldos de pensiones de censales del ausente (caja 5557, f. 89).

\section{Bienes de don José de Suelves y doña Manuela Lerín, su mujer*}

El 10-1-1708 Francisco Estadilla arrendó a Pedro la Villa los campos, viñas y olivares del ausente por 1 año, desde Navidad de 1707, por 80 libras (caja 5557, f. 37).

E1 2-12-1708 Juan Francisco Sobrecasas arrendó a Pedro Echegoyen, mercader y vecino de Zaragoza, unas casas del ausente sitas en la plaza del Mercado lindantes con las de doña Josefa Mauleón y otra del mismo ausente y su mujer, por 8 años, desde el 1 de enero de 1709 por 40 libras/año (caja 5557, ff. 166r-167v).

E1 15-4-1709 Diego Navarro, vecino de Zaragoza, se hizo fiador de don Manuel Sobrino, presbítero vecino de Zaragoza, que recibió de la Junta 80 escudos de los bienes del ausente (caja 5557, f. 379).

E1 1-3-1710 José Estorguía, maestro alarife y vecino de Zaragoza recibió de la Junta 10 libras 17 sueldos por reparos en casas del ausente (caja 5557, f. 510).

\section{Bienes de don Andrés Torrijos*}

El 13-3-1708 la parroquia de San Felipe presentó como fianza a Miguel Martín, maestro torcedor de seda, vecino de Zaragoza por haber recibido de la Junta 81 libras de pensiones del ausente (caja 5557, f. 77).

El 17-3-1708 Francisco Estadilla arrendó a Juan de Aso todos los campos, viñas, olivares y torre del ausente sitas en Zaragoza por 1 año (para las viñas desde Navidad de 1707, para lo demás desde San Juan de 1708), por 50 libras. Fianza: don Manuel Anes, vecino de Zaragoza (caja 5557, ff. 83r-84v).

\section{Bienes de don Gerónimo Nicolás Torrijos*}

E1 9-2-1708 don Gerónimo Piazuelo, gobernador de Caspe, nombró a Antonio Ondeano y José Ondeano, padre e hijo, para que pidieran a la Junta de los bienes del ausente el valor de 4 mulos de coche que le saquearon en la turbación y fueron a manos de Torrijos, que se los llevó al huir (caja 5557, f. 51).

El 16-4-1709 la Junta entregó a don Francisco Gacel, cirujano mayor del Hospital de Convalecientes de Zaragoza, al capitán Dagart, comisario de Víveres, al capitán Premont y al capitán Granier, a quienes les robaron al venir de Mequinenza, y por manos de don Nicolás Calvo, vecino de Zaragoza y depositario del ganado lanar y cabrío secuestrado del ausente, la cantidad de 24.466 reales de plata en ganado. Se añade que el mismo día don Sebastián de Eusa Torreblanca, del consejo de Hacienda y oidor de la chancillería, asistido por Roque Antonio Núñez y Francisco Gacel, fue a 
informar de dicho acto al Excmo. Sr. marqués de Jofreville, quien lo aprobó (caja 5557 , ff. $380 \mathrm{r}-381 \mathrm{v})$.

El 28-2-1710 don Nicolás Calvo, vecino de Zaragoza, recibió de la Junta 172 libras 13 sueldos por administrar el ganado lanar y cabrío del ausente (caja 5557, f. 508).

\section{Bienes de José Vidal, vecino de Muel}

El 6-2-1709 José Navarro, vecino de Zaragoza era fianza de José Navarro, titular de una capellanía en la parroquia de Muel, que recibió 27 libras 2 sueldos 8 dineros por pensiones de censales contra el secuestro de Vidal (caja 5557, f. 351).

El 15-3-1709 Diego Gonzalbo se hizo fiador de Bartolomé Ramo, beneficiado de Luco de Jiloca, que había pedido a la Junta 4.074 sueldos por réditos de dos censales contra los bienes del ausente, vecino de Luco (caja 5557, f. 372).

\section{Bienes de Martín Xavierre}

El 18-2-1709 Juan Francisco Sobrecasas arrendó a Domingo Barrán las viñas, campos y olivares del ausente por 1 año, desde el 1 de enero de 1709, por 20 libras (caja 5557, ff. 64r-65v).

\section{Bienes de Matías Xavierre*}

El 25-3-1708 Francisco Estadilla arrendó a Cristóbal Santaromana todos los campos, viñas y olivares del ausente en Zaragoza y barrios por 1 año desde Navidad de 1707 por 20 libras. Fianza: Domingo Barrao, vecino de Zaragoza (caja 5557, ff. 93r94v).

\section{Bienes de don José Ximénez}

El 21-11-1708 Antonio Casamayor, vecino de Tauste, se obligó a presentar fianza por haber recibido de la Junta 124 libras 1 sueldo de los bienes del ausente sitos en Pradilla (caja 5557, f. 163).

\section{Bienes de Martín Ximénez y Urriés}

El 11-5-1708 don Miguel López Generés, vecino de La Almunia, se hizo fianza del concejo de La Almunia por haber recibido 343 libras del ausente por el arriendo del molino de aceite en la villa (caja 5557, f. 107).

\section{Bienes de Bautista Pera [no se lee], vecino de Fraga}

E1 21-11-1708 Miguel Bodón, vecino de Fraga, se hizo fianza de los parroquianos de San Pedro y San Miguel de Fraga por los 510 sueldos del ausente pagados por pensiones de censales (caja 5557, f. 162).

\section{Bienes secuestrados de quienes no se menciona el dueño}

E1 25-9-1708 Juan Francisco Sobrecasas recibió de Valentín Oliván, vecino de Zaragoza, 55 libras por el arriendo de una casa secuestrada, correspondientes a la mitad del pago de 1707 y a la mitad del de 1708 (caja 5557, f. 148). 
También tres religiosos cobraron de la Junta pensiones de censales sin especificar contra quiénes lo estaban, en un caso 6 libras 5 sueldos (caja 5557, f. 111), en otro 20 libras (caja 5557, f. 113) y en el último 42 libras 5 sueldos (caja 5557, f. 169).

\section{ANEXO 4 \\ PERSONAS CON BIENES SECUESTRADOS EN ARAGÓN EN 1722 Y RENTA DE SUS BIENES BRUTA Y LÍQUIDA}

[El asterisco al final de un nombre indica que también aparecen en el listado del anexo 3] 972]

[Archivo General de Simancas. Secretaría y Superintendecia de Hacienda, legajo

\section{«Contaduría General de Bienes Confiscados}

Reino de Aragón

Relación de los valores líquidos que se considera tienen anualmente todos los bienes y rentas confiscados y secuestrados en el reino de Aragón por presupuesto del que tuvieron en el año 1720 , lo que importan las cargas de justicia anuales que hasta ahora se han justificado y el residuo que queda al año para satisfacción de las deudas causadas hasta fin del año 1717 y demás fines a que S. M. lo tiene aplicado. Todo ello conforme a las relaciones y noticias que se han remitido a la contaduría de la razón general de bienes confiscados de S. M. de mi cargo, por la de la superintendencia general de rentas y confiscaciones de aquel reino, que con distinción de lo correspondiente a cada estado y secuestro es en esta forma:

\begin{tabular}{|l|r|r|r|}
\hline $\begin{array}{l}\text { Secuestros por abecedario de los nom- } \\
\text { bres de los habientes [ese orden alfa- } \\
\text { bético se ha alterado, prefiriendo el del } \\
\text { apellido, y situando en primer lugar los } \\
\text { nobles, después el resto] }\end{array}$ & $\begin{array}{l}\text { Valor que se con- } \\
\text { sidera anualmente } \\
\text { por presupuesto } \\
\text { del año 1720 regu- } \\
\text { lados los granos a } \\
\text { mrs a los precios } \\
\text { que se le han dado } \\
\text { en él }\end{array}$ & $\begin{array}{l}\text { Cargas de } \\
\text { justicia } \\
\text { anuales que } \\
\text { hasta ahora } \\
\text { se han justi- } \\
\text { ficado }\end{array}$ & $\begin{array}{l}\text { Residuo anual } \\
\text { que se considera } \\
\text { para satisfacción } \\
\text { de cargas de } \\
\text { justicia y demás } \\
\text { fines a que está } \\
\text { aplicado }\end{array}$ \\
\hline Marquesado de Villafranca & 23.296 & 12.018 & 11.278 \\
\hline Condesa de Centellas & 87 & 0 & 87 \\
\hline Condado de Elda* & 89.545 & 41.739 & 4.100 \\
\hline $\begin{array}{l}\text { Condado de Fuentes y marquesado de } \\
\text { Mora* }\end{array}$ & 58.888 & 26.635 & 47.806 \\
\hline $\begin{array}{l}\text { Condado de Luna y sus baronías por la } \\
\text { mitad de sus frutos, que es lo que perte- } \\
\text { nene a la real hacienda }\end{array}$ & & 10.360 & 32.253 \\
\hline Baronía de Antillón* y de La Almolda & 10.032 & 2.145 & 7.887 \\
\hline ABARCA Y BOLEA, D. Manuel & 2.805 & 730 & 2.075 \\
\hline ÁGREDA, Francisco & 80 & 0 & 80 \\
\hline ÁGREDA, Miguel de* & 170 & 0 & 170 \\
\hline
\end{tabular}




\begin{tabular}{|c|c|c|c|}
\hline AGUARÓN, José & 220 & 0 & 220 \\
\hline AGUARÓN, José e INDIANO, Juan & 30 & 0 & 30 \\
\hline AGUARÓN, Miguel & 230 & 0 & 230 \\
\hline AÍNSA, D. Marcelo de* & 1.989 & 100 & 1.889 \\
\hline ALABER, Lamberto & 24 & 0 & 24 \\
\hline ALCALÁ, Tomás* & 160 & 0 & 160 \\
\hline ALCAYNA, Francisco & 95 & 0 & 95 \\
\hline ALCAYNA, Ignacio* & 400 & 0 & 400 \\
\hline ALCAYNA, Roque & 200 & 0 & 200 \\
\hline ALCOBER, Cosme & 32 & 0 & 32 \\
\hline ALEGRE, Francisco & 50 & 0 & 50 \\
\hline ALFARO, Francisco & 30 & 0 & 30 \\
\hline ALIAGA, D. Isidro & 576 & 0 & 576 \\
\hline ALIAGA, D. Isidro & 1.792 & 0 & 1.792 \\
\hline ALMANZÓN, Antonio & 35 & 0 & 35 \\
\hline ALMANZÓN, José & 30 & 0 & 30 \\
\hline ALMENARA, Francisco & 280 & 110 & 170 \\
\hline ANDRÉS, Antonio & 150 & 0 & 150 \\
\hline ANDRÉS, D. Pedro* & 4.884 & 779 & 4.105 \\
\hline ANTÓN, D. Gerónimo* & 4.492 & 550 & 3.942 \\
\hline AQUAVERA, D. José & 480 & 235 & 245 \\
\hline AYSA, Sebastián & 6 & 0 & 6 \\
\hline AZAILA, Manuel & 485 & 295 & 190 \\
\hline AZNAR, Salvador & 40 & 0 & 40 \\
\hline AZPIRIZ, Félix & 20 & 0 & 20 \\
\hline BALL, Juan & 22 & 0 & 22 \\
\hline BARBOTT, Sebastián & 832 & 110 & 722 \\
\hline BARDUZAL, Gabriel & 65 & 0 & 65 \\
\hline BARGAS, D. Manuel de & 437 & 0 & 437 \\
\hline BASQUAS, Diego & 32 & 0 & 32 \\
\hline BASQUAS, Pedro & 176 & 100 & 76 \\
\hline BELTRÁN, Domingo* & 300 & 0 & 300 \\
\hline BENAVIDES, D. Antonio de & 2.805 & 0 & 2.805 \\
\hline BERENGUER, D. Antonio & 2.924 & 0 & 2.924 \\
\hline BERNIZ, Pedro & 20 & 0 & 20 \\
\hline BLASCO, D. Teresa & 200 & 0 & 200 \\
\hline BLASCO, Juan Francisco & 25 & 0 & 25 \\
\hline BORAU, D. José* & 1.800 & 995 & 805 \\
\hline BORNAT, Pedro & 60 & 0 & 60 \\
\hline BUI, D. Eusebio & 300 & 0 & 300 \\
\hline BULOSSA, D. Pedro* & 300 & 0 & 300 \\
\hline BUTRÓN, D. Pedro* & 450 & 450 & 0 \\
\hline CABELLO, Luis & 120 & 120 & 0 \\
\hline
\end{tabular}




\begin{tabular}{|c|c|c|c|}
\hline CALBERA, José & 80 & 0 & 80 \\
\hline CALLEJA, Juan & 4 & 0 & 4 \\
\hline CAMPOS, Juan & 2 & 0 & 2 \\
\hline CASEDAS, Blas de & 24 & 0 & 24 \\
\hline \begin{tabular}{|l} 
CASTANEDA, Domingo \\
\end{tabular} & 50 & 0 & 50 \\
\hline CASTILLO, Félix* & 1.000 & 50 & 950 \\
\hline CASTRO, D. Antonio & 180 & 0 & 180 \\
\hline CASTRO, José Francisco & 45 & 0 & 45 \\
\hline CAUDEVILA, Juan & 90 & 0 & 90 \\
\hline CAVERO, D. Pedro & 300 & 300 & 0 \\
\hline CLABER, Miguel & 50 & 0 & 50 \\
\hline COCÓN, D. Francisco León & 32 & 0 & 32 \\
\hline COMA, Nicolás la* & 32 & 32 & 0 \\
\hline CONCLANTRILLO, D. Martín & 64 & 0 & 64 \\
\hline CONTAMINA, D. Manuel de & 978 & 304 & 674 \\
\hline COPONS, María & 200 & 0 & 200 \\
\hline CORELLA, D. Antonio & 520 & 0 & 520 \\
\hline CUELLO, Manuel & 18 & 0 & 18 \\
\hline DEZA, D. Francisco & 1.450 & 0 & 1.450 \\
\hline ENTRENA, Juan Antonio & 32 & 0 & 32 \\
\hline ESCOTO, D. Juan* & 225 & 0 & 225 \\
\hline ESCUELA, Blas & 10 & 0 & 10 \\
\hline ESMIR, D. Esteban* & 1.060 & 0 & 1.060 \\
\hline ESMIR, D. Francisco* & 2.358 & 640 & 1.718 \\
\hline ESTANGA, D. Agustín* & 600 & 250 & 350 \\
\hline ESTRELLA, Guillermo la & 20 & 0 & 20 \\
\hline ESTRELLA, José la & 32 & 0 & 32 \\
\hline FERRANDO, Jaime & 204 & 30 & 174 \\
\hline FERRER, Domingo & 112 & 0 & 112 \\
\hline FERRERO, D. Blas & 2.376 & 392 & 1.984 \\
\hline FERRERO, D. Blas & 2.480 & 0 & 2.480 \\
\hline FUENTES, D. Pedro de & 113 & 0 & 113 \\
\hline FUENTES, José de* & 48 & 0 & 48 \\
\hline GALINDO, Juan & 209 & 0 & 209 \\
\hline GALINDO, Martín & 168 & 0 & 168 \\
\hline GALLEGO, José & 16 & 0 & 16 \\
\hline GARAY, mayor y menor, Gerónimo* & 2.000 & 324 & 1.676 \\
\hline GARCÉS, D. Antonio & 612 & 0 & 612 \\
\hline GARCÍA, D. Diego & 300 & 0 & 300 \\
\hline GARCÍA, José Matías* & 100 & 0 & 100 \\
\hline GARÍN, Diego & 55 & 0 & 55 \\
\hline GASTÓN, Juan & 50 & 0 & 50 \\
\hline GAZO, D. Francisco* & 500 & 204 & 290 \\
\hline
\end{tabular}




\begin{tabular}{|c|c|c|c|}
\hline GIL, José & 100 & 0 & 100 \\
\hline GONZALES, Rafael & 70 & 0 & 70 \\
\hline GUADALAJARA, Miguel de & 260 & 0 & 260 \\
\hline GUARDINGO, Miguel Bautista & 80 & 0 & 80 \\
\hline GUILLÉN, Pedro & 24 & 24 & 0 \\
\hline HERAS, Manuel de las & 32 & 0 & 32 \\
\hline HERNÁNDEZ, Patricio & 68 & 0 & 68 \\
\hline IBÁÑEZ, D. Francisco* & 420 & 0 & 420 \\
\hline IBERO, Francisco & 2 & 0 & 2 \\
\hline IGLESIA, Domingo la & 8 & 0 & 8 \\
\hline IRANZU, José & 288 & 0 & 288 \\
\hline IRAZÁBAL, D. Gabriel** & 300 & 120 & 180 \\
\hline ITURRALDE, Gerónimo & 13 & 0 & 13 \\
\hline JAIME, José & 86 & 0 & 86 \\
\hline JINTO MANDURRA, Pedro & 2 & 0 & 2 \\
\hline JORARAN, Miguel & 140 & 50 & 90 \\
\hline JOSSA, José de & 100 & 0 & 100 \\
\hline JUSTE, Francisco & 80 & 0 & 80 \\
\hline LABALSA, Diego & 80 & 0 & 80 \\
\hline LABARTA, Domingo* & 110 & 0 & 110 \\
\hline LABAZUEI, José & 150 & 0 & 150 \\
\hline LABORDA, Domingo* & 200 & 95. & 105 \\
\hline LAFITA, D. Bartolomé y D. Frco.* & 400 & 400 & 0 \\
\hline LA-PORTA, D. Lucas* & 2.362 & 0 & 2.362 \\
\hline LA-PORTA, D. Lucas & 136 & 0 & 136 \\
\hline LA-TORRE, D. Luis* & 1.536 & 0 & 1.536 \\
\hline LAX, José & 40 & 0 & 40 \\
\hline LÁZARO, Antonio & 60 & 5 & 55 \\
\hline LEONARDO, D. José & 576 & 0 & 576 \\
\hline LEZCANO, Antonio & 6 & 0 & 6 \\
\hline LINARES, D. Manuel de & 228 & 0 & 228 \\
\hline LINARES, D. Manuel de & 238 & 0 & 238 \\
\hline LÓPEZ DE ZENEDO, Joaquín & 50 & 0 & 50 \\
\hline LUCÍA, Antonio & 120 & 0 & 120 \\
\hline LUZÁN, D." Gertrudis & 1.645 & 0 & 1.645 \\
\hline LUZAS, José & 360 & 100 & 260 \\
\hline MAGALLÓN, Manuel & 60 & 0 & 60 \\
\hline MANDURRA, Jacinto & 23 & 0 & 23 \\
\hline MANUEL, D. José* & 506 & 134 & 372 \\
\hline MARTUREL, José & 50 & 0 & 50 \\
\hline MAYOR, Francisco & 60 & 0 & 60 \\
\hline MENDOZA, D. José* & 770 & 390 & 380 \\
\hline MIRAVETE, Antonio & 25 & 0 & 25 \\
\hline
\end{tabular}




\begin{tabular}{|c|c|c|c|}
\hline MOLINA, D. Antonio & 520 & 0 & 520 \\
\hline MOLÍNS, D. Antonio & 210 & 0 & 210 \\
\hline MONREAL, Pedro & 300 & 0 & 300 \\
\hline MONTES, D. Juan Antonio* & 270 & 270 & 0 \\
\hline MORA, Bernardo & 20 & 0 & 20 \\
\hline MORALES, Juan* & 20 & 0 & 20 \\
\hline MORÓN, Antonio José & 448 & 76 & 372 \\
\hline MUGÍN, José & 172 & 64 & 108 \\
\hline NARBIÓN, Antonio* & 308 & 0 & 308 \\
\hline NARBIÓN, Bartolomé & 36 & 0 & 36 \\
\hline NAVARQUEZ, D. Francisco & 1.000 & 1.000 & 0 \\
\hline NAVARRO, Antonio & 4 & 0 & 4 \\
\hline NAVARRO, José & 60 & 0 & 60 \\
\hline NAVARRO, Marcos & 271 & 0 & 271 \\
\hline NAYA, D. Antonio & 300 & 0 & 300 \\
\hline ORERA, D. ${ }^{a}$ Teresa* & 880 & 479 & 401 \\
\hline ORERA, D." Teresa de* & 600 & 0 & 600 \\
\hline OZCÁRIZ, D. José* & 1.862 & 650 & 1.212 \\
\hline PANO, Miguel & 100 & 0 & 100 \\
\hline PARGADA, Gerónimo & 16 & 0 & 16 \\
\hline PASQUAL, Juan & 55 & 0 & 55 \\
\hline PÉREZ DE LAS AGUAS, D. José* & 320 & 320 & $\begin{array}{r}320 \\
\text { [debería ser } 0] \\
\end{array}$ \\
\hline PÉREZ, Blas & 10 & 0 & 10 \\
\hline PÉREZ, José & 101 & 0 & 101 \\
\hline PINILLA, Vicente & 80 & 0 & 80 \\
\hline PUJOL, Antonio & 250 & 100 & 150 \\
\hline PUJOL, D. Antonio & 200 & 0 & 200 \\
\hline QUIBUS, José* & 81 & 0 & 81 \\
\hline QUINTANA, Antonio & 32 & 0 & 32 \\
\hline RAM, José & 22 & 0 & 22 \\
\hline RIBAS, D. Manuel de* & 1.033 & 0 & 1.033 \\
\hline RIBERA, José & 150 & 0 & 150 \\
\hline Río, D. Félix del* & 600 & 0 & 600 \\
\hline RÍO, D. Félix del* & 180 & 0 & 180 \\
\hline RODRIGO, Domingo & 34 & 0 & 34 \\
\hline RONCHALES, Juan & 10 & 0 & 10 \\
\hline ROY, Miguel & 40 & 0 & 40 \\
\hline RUIZ, Lorenzo & 16 & 0 & 16 \\
\hline SAGARRA, Alejos & 200 & 0 & 200 \\
\hline SAHÚN, Andrés & 28 & 0 & 28 \\
\hline SALANOVA, Francisco & 350 & 0 & 350 \\
\hline SALINAS, D. Agustín & 150 & 150 & 0 \\
\hline
\end{tabular}




\begin{tabular}{|c|c|c|c|}
\hline SAN MARTÍN, D. Jorge & 610 & 416 & 194 \\
\hline SÁNCHEZ, Manuel & 1.050 & 70 & 980 \\
\hline SANCHO, Francisco & 18 & 0 & 18 \\
\hline SANTAS, Juan de & 70 & 0 & 70 \\
\hline SENDRE, Jacinto & 80 & 0 & 80 \\
\hline SENDRE, José & 8 & 0 & 8 \\
\hline SENDRE, Urbano & 60 & 0 & 60 \\
\hline SOLANO, Antonio & 542 & 165 & 377 \\
\hline SOLANO, D. Antonio & 452 & 0 & 452 \\
\hline SUELVES, D. José de* & 4.542 & 817 & 3.725 \\
\hline TAFALLES, Juan & 192 & 1.28 & 64 \\
\hline TARDíO, Julián & 110 & 0 & 110 \\
\hline TENA, Pedro & 80 & 0 & 80 \\
\hline TERRAZA, Ignacio & 130 & 0 & 130 \\
\hline TERRER CASADO, José & 864 & 100 & 764 \\
\hline TORRENTE, Gaspar & 12 & 0 & 12 \\
\hline TORRIJOS, D. Andrés* & 850 & 850 & 0 \\
\hline TORRIJOS, D. Andrés* & 512 & 100 & 412 \\
\hline TORRIJOS, D. Gerónimo* & 910 & 450 & 460 \\
\hline URRACA, Juan & 170 & 0 & 170 \\
\hline VICENTE, Juan & 80 & 0 & 80 \\
\hline VILLA, Julián & 64 & 0 & 64 \\
\hline VILLACAMPA, D. Pedro & 1.740 & 1.025 & 715 \\
\hline VILLANOVA, Domingo & 6 & 0 & 6 \\
\hline VILLANOVA, Francisco & 32 & 0 & 32 \\
\hline VILLAR, D. Simón del & 691 & 100 & 591 \\
\hline VILLAREAL, José & 35 & 0 & 35 \\
\hline XAVIERRE, Matías* & 400 & 45 & 355 \\
\hline XIMÉNEZ, Clemente & 120 & 0 & 120 \\
\hline XIMÉNEZ, D. Pablo & 380 & 105 & 275 \\
\hline YUS, Gerónimo de & 48 & 0 & 48 \\
\hline \multirow[t]{2}{*}{ ZACUERCA, Antonio } & 40 & 40 & 0 \\
\hline & 279.761 & 104.415 & 175.346 \\
\hline \multirow[t]{2}{*}{$\begin{array}{l}\text { Bajas del residuo: } \\
\text { Importan los salarios y gastos de admi- } \\
\text { nistración de estas haciendas exclusos } \\
\text { los del estado de Luna, que van conside- } \\
\text { rados en sus cargas } 15.464 \text { rs. de plata } \\
\text { que se consideran por menos residuo y } \\
\text { más aumento de cargas }\end{array}$} & 0 & 15.464 & 15.464 \\
\hline & 279.761 & 119.879 & 159.882 \\
\hline
\end{tabular}




\begin{tabular}{|c|c|c|c|}
\hline $\begin{array}{l}\text { Bajas del valor: } \\
\text { Consideranse por menos valor de las } \\
\text { rentas y por consiguiente de baja en el } \\
\text { residuo por ahora } 58.061 \text { rs. de plata, } \\
\text { los } 40.000 \text { de ellos que se considera } \\
\text { se necesitaron cada año para reparos } \\
\text { de posesiones y los } 18.061 \text { restantes } \\
\text { de diferentes censos pertenecientes al } \\
\text { marquesado de Villafranca, que por ser } \\
\text { impuestos sobre efectos de cruzada, no } \\
\text { se perciben por el fisco }\end{array}$ & 58.061 & 0 & 58.061 \\
\hline & 221.700 & 119.879 & 101.821 \\
\hline
\end{tabular}

Por manera que en la forma expresada en esta relación importa el valor anual de todas las rentas confiscadas y secuestradas en el reino de Aragón doscientos veintiun mil setecientos reales de plata doble, las cargas que sobre sí tienen según las justificaciones hechas hasta ahora, inclusos los salarios y gastos de administración, ciento diecinueve mil ochocientos setenta y nueve reales de plata. Quedan de residuo al año ciento un mil ochocientos veintiún reales de la misma especie, que reducido todo ello a vellón de Castilla importa el dicho valor cuatro cientos quince mil seiscientos ochenta y siete reales, las cargas doscientos veinticuatro mil setecientos setenta y tres, y el residuo ciento noventa mil novecientos catorce reales, conforme a las relaciones y noticias remitidas a la contaduría de mi cargo por la de aquel reino. Fecha en Madrid, a diecisiete de septiembre de 1722. Miguel Rosa〉.

ANEXO 5

BIOGRAFÍAS DE AUSTRACISTAS QUE FUERON CIUDADANOS DE ZARAGOZA

[El paréntesis indica en qué anexos aparecen citados]

\section{Marcelo de AínSA (A3, A4)}

Licenciado y doctor en Leyes en febrero de 1680.

En 1697 y 1698 se estudió y aceptó la petición de insaculación en bolsa $4 .^{a}$ de oficios.

[ACA, legajo 112. AMZ, caja 7771, n. ${ }^{\circ}$ 1. M. JMÉNEZ CATALÁN, Memorias para la Historia de la Universidad Literaria de Zaragoza..., p. 357].

\section{Pedro José ANDRÉS (A3, A4)}

En 1679 fue insaculado en bolsa 5. de oficios y correspondientes.

Ejerció como Juez de residencia de bolsa 5 . $^{\text {a }}$ en 1691 y como consejero de la misma en 1693.

En un memorial de petición de ascenso a bolsa $4 .^{\mathrm{a}}$ explicaba que era secretario de la Inquisición y que su abuelo Juan Isidoro sirvió la misma secretaría y los empleos de escribano de mandamiento en la cancillería y secretario de estado y guerra del virrey, 
siéndolo el condestable de Castilla en 1644; fue jurado $4 .^{\circ}$ también. Juan Francisco Andrés, hermano de su abuelo, fue alguacil mayor y secretario de la Inquisición en Cataluña, Mallorca y Sevilla. Diego Miguel Andrés, su padre, fue secretario de la Inquisición y escribano de mandamiento, y en 1690 el rey le dio título de secretario del consejo supremo de Aragón. El suplicante hacía 8 años que era secretario de la Inquisición como su padre y abuelo, que como hidalgos fueron a Cortes.

En 1705 se aceptó su propuesta de ascenso a 4 a $^{\text {a }}$ demás correspondientes.

[ACA, legajos 109, 110, 112, 121. AHN, Consejos, libro 2273, f. 190r. AMZ, libro de actos comunes de 1680 , f. 33].

\section{Gerónimo ANTÓN Y SAYAS (A3, A4)}

En 1683 se estudió su insaculación y la ciudad propuso la bolsa 2. ${ }^{a}$, dispensando la ordinación 67, alegando que su padre, Gerónimo Francisco Antón y Esteban, era entonces jurado $1 .^{\circ}$ y diputado del reino, y que el suplicante sirvió en las cortes de 1678. En el mismo año, en una carta a don Pedro de Aragón del consejo de Aragón, un informante destacaba que Gerónimo Antón ofreció 1.000 doblones por la futura de capitán de guardias de la Guardia del Reino y después 1.000 reales de a ocho más. Finalmente en 1687 fue insaculado en bolsa 3."

En 1691 se estudió su asunción a bolsa $2 .^{a}$ y correspondientes, con dispensa de edad para servir los oficios si sorteaba. Era capitán de las guardias de a pie y de a caballo.

El consejo de Aragón consultó en 1693 a favor de asunción a 1. ${ }^{a}$

Fue lugarteniente de zalmedina en 1692. Zalmedina en 1693. Consejero de bolsa 1. en 1694. Zalmedina en 1697, aunque iba para lugarteniente, pero en enero de dicho año murió el que debía ser zalmedina, José de Blancas.

En 1698 se le dispensó la edad para servir el oficio de jurado $1 .^{\circ}$

Juez de residencia de bolsa 1 en 1699. Consejero de bolsa $1 .^{a}$ en 1699.

En abril de 1703 el rey le permitió disponer del oficio de capitán de guardias de a pie y caballo en hijo o sobrino o hermano, sin perjuicio de la futura dada a Juan Ulzurrun de Asanza para uno de sus hijos.

Jurado $1 .^{\circ}$ en 1705 y consejero en 1706 . Jurado $1 .^{\circ}$ desde enero de 1707 por nombramiento directo del Archiduque, siendo destituido por el duque de Orleans en mayo. Por su austracismo fue consejero de bolsa $1 .^{\text {ad }}$ desde agosto hasta diciembre de 1710 por nombramiento del Archiduque.

[ACA, legajos 41, 76, 108, 109, 115; registro 98, ff. 137v, 138v. AHN, Consejos, libro 2288, ff. 28v-32r. AMZ, libros de actos comunes de 1706, 1707, 1710; caja 7771, n. $\left.{ }^{\circ} 1\right]$.

\section{José BORAU (A3, A4)}

En un memorial explicaba que su abuelo Pedro Martín y su padre Pedro Pablo fueron ciudadanos y murieron insaculados en $2 .^{\text {a }}$ Pedía entrar en $4 .^{a}$ y correspondientes.

[ACA, leg. 112]. 


\section{Félix CASTILLO (A3, A4)}

En un memorial explicaba que era hijo de Sebastián Castillo y pedía acceder a 5. ${ }^{\text {a }}$ Los dos asistieron a Cortes de 1678 y habían ocupado puestos de la parroquia de San Pablo.

[ACA, leg. 112].

\section{Pedro Luis CAVERO (A4)}

En 1679 se estudió su insaculación en 3 a $^{\text {a }}$ correspondientes, teniendo en cuenta sus servicios en las últimas Cortes.

Fue consejero de bolsa $3 .^{a}$ en 1686. Lugarteniente de zalmedina en 1687. Zalmedina en 1688 .

Consejero de bolsa 1. ${ }^{\text {a }}$ en 1693 y 1697 y desde agosto hasta diciembre de 1710 por nombramiento del Archiduque.

[ACA, legajos 110, 121. AMZ, libros de actos comunes de 1686, 1710].

\section{Manuel de CONTAMINA Y ORTAL (A4)}

En 1676 se estudió su insaculación en alguna bolsa teniendo en cuenta los méritos de su padre y familia, y finalmente accedió a 3. ${ }^{a}$ Tras su paso por 2. ${ }^{a}$ fue asumido a bolsa 1." por la ciudad en 1680. En 1681 se le dispensó la ordínación sobre edad para servir los oficios de la ciudad y así servir el de jurado $1 .^{\circ}$ si sorteaba.

Consejero de bolsa 2." en 1680. Consejero de bolsa 1." en 1685. Jurado 1. en 1686 (año en que ingresó en la bolsa de administrador del puente de madera) y consejero en 1687. Lugarteniente de zalmedina en 1697. Zalmedina en 1698 [estos dos cargos pudo tenerlos otra persona pues las fuentes no son claras]. Consejero de bolsa $1 .^{a}$ en 1700 . Jurado $1 .^{\circ}$ desde agosto hasta diciembre de 1710 nombrado por el Archiduque.

[ACA, legajos 109, 112, 121; registros 81, 86, 89. AMZ, libros de actos comunes de $1676,1680,1686,1710$; caja 7772, n. $\left.^{\circ} 6\right]$.

\section{Esteban ESMIR SERÁN Y CASANATE (A3, A4)}

En 1674 fue insaculado en 2. ya que había alegado los méritos de su padre Juan Antonio Esmir y de su abuelo, y además estaba casado con la nieta del regente del consejo Pedro Villacampa y Pueyo.

Consejero de bolsa 2. en 1675. En 1678 se le dispensó la obligación de tener 35 años para ser jurado $2 .^{\circ}$ Juez de residencia de bolsa $2 .^{a}$ en 1680 . Jurado $2 .^{\circ}$ en 1681.

La ciudad en 1684 se mostró a favor de que entrara en bolsas de padre de huérfanos, administrador del puente madera, comprador de pan y carne y colateral de esa administración.

Fue consejero de bolsa $2 .^{a}$ en 1684 . Lugarteniente de zalmedina en 1685. Zalmedina en 1686. Consejero de bolsa $2{ }^{a}$ en 1686.

El gobernador en 1687 explicaba que era señor de Ballerías, y receptor general de las bailías en el Reino.

En 1686-87-88 se estudió su ascenso a 1. y correspondientes y se le dispensó la edad necesaria para ser jurado $1 .^{\circ}$ 
Consejero de bolsa $1 .^{a}$ en 1691. Jurado $1 .^{\circ}$ en 1692 y consejero en 1693, en 1695 y en 1697 . Jurado $1 .^{\circ}$ en 1706 . Consejero de bolsa $1 .^{\text {a }}$ desde enero de 1707 por nombramiento directo del Archiduque.

[ACA, legajos 111, 112, 113, 116, 121; registros 81, 84, 86, 93. AMZ, libros de actos comunes de $1675,1678,1680,16861695,1706,1707$; caja 7772, n. $\left.^{\circ} 6\right]$.

\section{Agustín de ESTANGA (A3, A4)}

Natural de Zaragoza. Licenciado y doctor en Leyes en 1654.

Fue insaculado en bolsa $4 .^{a}$ de oficios en 1658 y en $3 .^{a}$ en 1669. En 1671-72 se estudió su ascenso a bolsa $2 .^{\mathrm{a}}$ y en 1679-80 a $1 .^{\mathrm{a}}$

Asesor del zalmedina desde marzo de 1661 . Consejero de bolsa 1 l. $^{a}$ en 1685 y 1695. Jurado $1 .^{\circ}$ en 1700 y consejero en 1701 y en 1706.

[ACA, legajos 109, 110, 112, 121. AMZ, libros de actos comunes de 1672, 1680, 1695, 1706. M. JIMÉNEZ CATALÁN. Memorias..., p. 342].

\section{Pedro Gerónimo de FUENTES (A4)}

Natural de Zaragoza. Licenciado y doctor en Leyes en 1688. Abogado del Colegio de su ciudad. Lugarteniente de la corte del Justicia en 1699. Dejó escritas obras inéditas.

Fue insaculado en bolsa $4 .^{\text {a }}$ en 1669.

Consejero de bolsa $4 .^{\text {a }}$ en 1673 y en 1676 . Asesor del zalmedina en 1680 .

En noviembre de 1680 estaba en $3 .^{a}$

En 1687, siendo lugarteniente de la corte del Justicia, fue asumido a bolsa $2 .^{\mathrm{a}}$ y en 1691 se estudió su asunción a $1 .{ }^{\mathrm{a}}$

Almutazaf en 1698. Consejero de bolsa $1 .^{a}$ en 1698 y en 1700 . Asesor del zalmedina desde agosto de 1702. Repitió en 1703, 1704, 1705 y 1706 (fue ratificado por el Archiduque, que además le concedió el cargo de por vida).

En septiembre de 1703 se le encargó la insaculación de Alcañiz con Gerónimo Torrellas como notario.

Consejero de bolsa $1{ }^{a}$ en 1706. Consejero de bolsa 1. ${ }^{a}$ desde enero de 1707 por nombramiento directo del Archiduque, y el mismo cargo desde agosto hasta diciembre de 1710.

[ACA, legajos 111, 116, 121. AHN, Consejos, libro 2273, ff. 123v-126v. AMZ, libros de actos comunes de 1676, 1706, 1707, 1710; caja 7771, n. ${ }^{\circ}$; caja $7772, n{ }^{\circ} 6$. M. JIMÉNEZ CATALÁN. Memorias..., p. 362].

\section{Diego GARCÍA (A4)}

Fue insaculado en 1686 en bolsa $5 .^{a}$

Ejerció como consejero de bolsa $5 .^{\mathrm{a}}$ en 1697 . Jurado $5 .^{\circ}$ en 1698 y consejero en 1699. Síndico a tributar de bolsa $4 .^{a}$ en 1700 . Seguía en $4 .^{a}$ en la revisión de noviembre de 1703.

[ACA, legajos 116, 121. AMZ, libro de actos comunes de 1686]. 


\section{Félix GARCÍA LORENTE (A3)}

En 1687 se decidió su acceso a bolsa $4 .^{a}$ y correspondientes. Su abuelo José Gabriel Martín fue jurado 3. , y su padre Pedro García estuvo en 4. a Seguía en 4. a en la revisión de noviembre de 1703 .

[ACA, legajo 114].

\section{Francisco GAZO (A3, A4)}

En 1695 se estudió su asunción a $3 .^{a}$ y correspondientes, en la que estaba en la revisión de noviembre de 1703 .

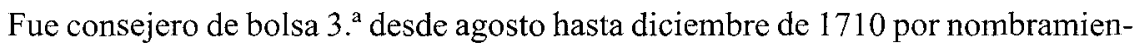
to del Archiduque.

[AMZ, libro de actos comunes de 1710 , caja 7771, n. $\left.^{\circ} 1\right]$.

\section{Manuel Miguel de GUADALAJARA (A4)}

En 1697 se insaculó a este infanzón, que había servido en Cortes, al igual que sus familiares, en $5 .^{\mathrm{a}} \mathrm{y}$ correspondientes.

Fue jurado $5^{\circ}$ desde agosto hasta diciembre de 1710 por nombramiento del Archiduque.

[ACA, legajo 112. AMZ, libro de actos comunes de 1710; caja 7771, n. ${ }^{\circ} 1$ ].

\section{Francisco IBÁÑEZ DE AOIZ (A3, A4)}

En 1679 se estudió y aceptó su insaculación en bolsa $4 .^{\text {a }}$ y correpondientes. En 1684-85 a $3 .^{a}$

Ejerció como consejero de bolsa 2. a en 1698 y jurado 2. ${ }^{\circ}$ en 1706.

[ACA, legajos 107, 113, 116. AMZ, libro de actos comunes de 1706].

\section{Gabriel de IRAZÁBAL (A3, A4)}

En 1687 fue insaculado en $5 .^{\text {a }}$ bolsa de oficios y el rey dispensó en 1690 la ordinación 74 .

Fue consejero de bolsa $5 .^{\mathrm{a}}$ en 1694 . Jurado $5 .^{\circ}$ en 1700 y consejero en 1701.

Seguía en esta bolsa en la revisión de 1703.

[ACA, legajos 115, 121; registro 94, f. 96v. AMZ, caja 7772, n. ${ }^{\circ} 6$ ].

\section{José MANUEL (A3, A4)}

En un memorial explicaba que era hidalgo y regente de la escribanía fiscal de la corte del Justicia hacía más de 14 años, y que en 1677 la ciudad y el virrey apoyaron su acceso a 5. ' bolsa, pero estaba detenida su incorporación. Finalmente accedió e incluso en 1691 se estudió su insaculación en 4 . $^{\mathrm{a}}$ Su padre, el ciudadano Juan Francisco Manuel, sirvió en las guerras de Cataluña en 1646 y el suplicante en las cortes de 1678 en el estamento de caballeros hijosdalgo y en la junta de brazos de 1684. Estaba en 5. en la revisión de noviembre de 1703. Fue consejero de bolsa 5. en 1705. Tuvo el mismo cargo desde enero de 1707 por nombramiento directo del Archiduque y el de jurado $4{ }^{\circ}$ desde agosto hasta diciembre de 1710 . 
[ACA, legajo 111, registro 93, f. 13v. AMZ, libros de actos comunes de 1706, 1707, 1710; caja 7771, n. $\left.^{\circ} 1\right]$.

\section{José MENDOZA (A3, A4)}

Estaba insaculado en bolsa 4. ${ }^{a}$ en 1695 y seguía en noviembre de 1703.

Fue lugarteniente de zalmedina desde agosto de 1710 por nombramiento del Archiduque.

[AMZ, libros de actos comunes de 1695, 1710].

\section{Juan Antonio MONTES (A3, A4)}

En 1691 se estudió su insaculación en $5 .^{a}$ bolsa de oficios. Estaba casado con la hija de Pedro Pablo Cebrián, que era jurado 3. En 1697 se le asumió a 4. ${ }^{a}$, donde seguía en 1703.

[AMZ, libro de actos comunes de 1697, f. 29v; caja 7771, n..$^{\circ}$ ].

\section{José OZCÁRIZ Y FERRER (A3, A4)}

Licenciado y doctor en Leyes en 1679.

Desde 1685 se estudió su insaculación, que finalmente se hizo en bolsa 3. ${ }^{a}$ de oficios y correspondientes en 1687, destacándose que su padre, José Ozcáriz y Vélez, sirvió muchos años, incluso como jurado $1 .^{\circ}$, y por entonces era ministro civil de la audiencia. El suplicante también alegó sus servicios en las cortes de 1678 y en la junta de brazos en el brazo de hijosdalgo.

En 1695 se decidió su asunción a 1.a, ya que estaba en la audiencia criminal y por ser ministro real le correspondía $1 .^{a}$

Fue Juez de residencia de bolsa $1 .^{a}$ en 1698 . Consejero de bolsa $1 .{ }^{a}$ en 1700,1706 y desde enero de 1707 por nombramiento directo del Archiduque.

[ACA, legajos 109, 114, 116, 121. AHN, Consejos, libro 1896, f. 91v. AMZ, libros de actos comunes de 1706, 1707; caja 7771, n. ${ }^{\circ} 1$, caja 7772 , n. ${ }^{\circ}$ 6. M. JIMÉNEZ CATALÁN. Memorias..., p. 357].

\section{José Miguel PÉREZ DE LAS AGUAS (A3, A4)}

En 1686 se ordenó que fuera insaculado en $4 .^{a}$ bolsa de ofícios, y en 1691 que fuera asumido a $3 .^{a}$, donde seguía en noviembre de 1703.

Fue consejero de bolsa $3{ }^{\text {a }}$ desde enero de 1707 por nombramiento directo del Archiduque.

Jurado $3{ }^{\circ}$ desde agosto hasta diciembre de 1710 [escrito José Manuel Pérez de las Aguas].

[ACA, registro 90, f. 71. AMZ, libros de actos comunes de 1706, 1707, 1710; caja $\left.7771, \mathrm{n}^{\circ} 1\right]$.

\section{Antonio PUJOL}

En un memorial de 1672 explicaba que era infanzón natural de Alagón, regente sustituto de la escribanía de la audiencia de Aragón hacía más de 12 años. Pedía 5. ${ }^{\mathrm{a}}$ y correspondientes.

[ACA, legajo 111]. 


\section{Manuel de RIBAS Y CAVERO (A3, A4)}

A fines de 1680 se estudió y aceptó su insaculación en bolsa $3 .^{a}$ de oficios, siendo además hijo y nieto de jurado $1 .^{\circ}$ En 1687 lo mismo para bolsa $2 .^{a}$ y en 1691 ya estaba en $1 . "$

Ocupó numerosos cargos: Jurado $1 .^{\circ}$ en 1691 y consejero en 1692. Lugarteniente de zalmedina en 1693. Zalmedina en 1694. Consejero de bolsa 1. ${ }^{a}$ en 1694. Juez de residencia de bolsa $1 .^{\text {a }}$ en 1696 . Consejero de bolsa $1 .^{a}$ en 1697 y en 1706 . Consejero de bolsa 1." desde enero de 1707 por nombramiento del Archiduque y lo mismo desde agosto hasta diciembre de 1710 .

[ACA, legajos 107, 112, 115, 121. AMZ, libros de actos comunes de 1706, 1707, 1710; caja $7771, n .^{\circ} 1$ y caja $\left.7772, n .^{\circ} 6\right]$.

\section{Gerónimo Félix del RÍO (A3, A4)}

A fines de 1687 se estudió y aceptó su inserción en bolsa $4 .^{a}$ de oficios, y en 1691 su ascenso a $3{ }^{a}$ y correspondientes.

En varios memoriales datables en 1698 explicaba que desde 1680 era procurador fiscal del rey y procurador principal de la ciudad, continuando los servicios de su tío Juan Francisco del Río que estuvo más de 30 años en el oficio. Este tío era jurado 2. ${ }^{\circ}$ en 1678, año en que vino el rey y hubo cortes, presidiendo el brazo de universidades, y también estuvo en la intervención de las cuentas de la Cruzada por el racional. El suplicante fue en 1697 consejero y miembro de la junta que se formó con motivo de la guerra de Cataluña. También había servido en las cortes de 1678 y junta de brazos de 1686-87, interviniendo en el brazo de caballeros hijosdalgo. Por todo esto y servicios de su tío pedía asunción a 2. ${ }^{\text {a }}$ y correspondientes y además en las de padre de huérfanos, administrador del puente de madera, administrador-comprador de pan y carne y colateral de dichas administraciones.

En un documento notarial se dice que era señor de los lugares de Lardiés y Sanfelices y pardinas de Castiello y Gorroba (A.H.P.N.Z. José López de Ruesta, 2-61701).

Estaba en bolsa 3. ${ }^{a}$ en la revisión de noviembre de 1703. En 1705 se estudió su ascenso a $2 .^{\text {a }}$, que no parece que alcanzó ya que fue jurado $3 .^{\circ}$ desde enero de 1707 por nombramiento directo del Archiduque. Su austracismo notorio explican que el duque de Orleans lo destituyera en mayo de este año. A raíz de la batalla de Zaragoza de 1710 y de la momentánea reconquista de la ciudad el Archiduque le nombró consejero de bolsa $3 .^{\text {a }}$ desde agosto hasta diciembre de 1710 .

[ACA, legajos 109, 112, 114, 121. AHN, Consejos, libro 2273, f. 199r. AMZ, libros de actos comunes de $1706,1707,1710$; caja 7771, n. $\left.^{\circ} 1\right]$.

\section{Jorge de SAN MARTÍN (A4)}

En dos memoriales, uno de 1705, explicaba que su padre Diego de San Martín sirvió al rey más de 40 años en empleos militares hasta morir como castellano de Baya en Nápoles. Pedía insaculación en 3. ${ }^{\mathrm{a}} \mathrm{y}$ correspondientes por estar su padre en $1 .^{\mathrm{a}}$ y ser el suplicante yerno de nieto y bisnieto de ciudadano. 
Zalmedina desde agosto de 1710 por el Archiduque.

[ACA, legajo 109. AHN, Consejos, libro 2273, f. 177. AMZ, libro de actos comunes de 1710$]$.

\section{Francisco SERRA Y ARDID (A3)}

En un memorial explicaba que era hijo y nieto de ciudadano y que su bisabuelo, micer Gerónimo Ardid, estuvo insaculado en 1. ${ }^{\mathrm{a}}$ y sus antepasados habían servido en la guerra de Cataluña. Estaba casado con hija de jurado 1. ${ }^{\circ}$ Por todo ello pedía acceder a $3 .^{a}$ bolsa de oficios y correspondientes. El rey pidió informe en septiembre de 1705 sobre esta petición.

[ACA, legajo 109. AHN, Consejos, libro 2273, f. 200r].

\section{Juan Antonio SOLANO (A4)}

En un memorial de 1696 explicaba que era hidalgo y sus abuelos y los de su mujer, Valera Monforte, habían sido ciudadanos y servido oficios. Había tenido a su cargo en el último septenio el cobro del maravedí y otros derechos del real patrimonio en las ciudades de Tarazona, Alcañiz y sus partidos. Aumentó esta real hacienda en 14.000 reales de plata sobre los siete años anteriores. En atención a todos los esfuerzos que esto le había costado y que a los comisarios antecedentes se les dio también alguna merced, pedía insaculación en 5.a , cosa que ocurrió en noviembre de 1697 . Fue juez de residencia de esta bolsa en 1699 .

En tres memoriales de 1702 y 1703 explicaba que era consejero de 5. ${ }^{a}$ bolsa en 1702 y pedía dispensa de la ordinación 76 que impedía ser jurado al que tenía cargo y empleo de un libro en la administración y arriendo de las generalidades del Reino, alegando sus méritos.

Estaba en 5. en la revisión de 27-11-1703.

[ACA, legajos 41, 109, 112, 121. AMZ, caja 7771, n. $\left.{ }^{\circ} 1\right]$.

\section{José SUELVES Y RUBALCAVA (A3, A4)}

[Aparece en otros lugares citado como José Suelves y Aranguren].

Licenciado y doctor en Leyes en 1686. Catedrático de la Universidad de Zaragoza, de Sexto, Decreto y al fin Vísperas de Cánones. Renunció a la misma en agosto de 1706.

Fue insaculado en bolsa 3. ${ }^{\mathrm{a}}$ de oficios en 1669. Consejero de bolsa 3." en 1679 , año en que fue asumido a $2 .^{\circ}$ Jurado $2 .^{\circ}$ en 1686 y consejero en 1687 , año en que fue asumido a 1. destacándose que había servido en la última reunión de brazos de las Cortes. Consejero de bolsa 1.a en 1692 y en 1698.

[ACA, legajos 109, 112, 116; reg. 89, f. 329. AMZ, libros de actos comunes de 1680, 1686. M. JIMÉNEZ CATALÁN. Memorias..., p. 361].

\section{Andrés TORRIJOS (A3, A4)}

Fue Síndico a tributar de bolsa $4 .{ }^{a}$ de oficios en.1697. En noviembre de este año se le asumió a bolsa 3. y correspondientes, en las que estaba en la revisión de noviembre 
de 1703 . Fue jurado $3 .^{\circ}$ en 1705 , consejero en 1706 y de nuevo consejero de bolsa $3 .^{a}$ desde enero de 1707 por nombramiento directo del Archiduque Carlos.

[ACA, legajo 121. AMZ, libros de actos comunes de 1706, 1707; caja 7771, n. $^{\circ}$ 1].

\section{Gerónimo TORRIJOS Y VIRTO (A3, A4)}

En diciembre de 1693 la ciudad de Zaragoza apoyó su insaculación en bolsa $3{ }^{a}$ de oficios y correspondientes de este proveedor de los presidios del reino. En noviembre de 1697 se ordenó su asunción a $2{ }^{\text {a }}$ y correspondientes. Fue Juez de residencia de esta bolsa y consejero en 1699 .

En memoriales de 1702 explicaba que era veedor de la gente de guerra y presidios de Aragón; que había renunciado a la calidad de ciudadano para entrar en el brazo de caballeros en las cortes de este año, donde hizo lo que el regente Miguel de Jaca y el protonotario José de Villanueva indicaron. Llevaba muchos años en 2. ${ }^{a}$ y pedía volver como ciudadano insaculado en bolsa $1 .^{a}$ o si no con el oficio de lugarteniente de zalmedina. Al margen de su petición se anotó que no había lugar a esto. Estaba en $2 .^{a}$ en la revisión de bolsas de noviembre de 1703 .

Consejero de bolsa $1 .{ }^{\text {a }}$ desde agosto hasta diciembre de 1710 por nombramiento del Archiduque

[ACA, legajos 41, 109, 112. AMZ, libro de actos de 1710, caja 7771, n. ${ }^{\circ} 1$ ]. 